\title{
Predictive and Prognostic Protein Biomarkers in Epithelial Ovarian Cancer: Recommendation for Future Studies
}

\author{
Cécile Le Page ${ }^{1}$, David G. Huntsman ${ }^{2,3}$, Diane M. Provencher ${ }^{1,4}$ and Anne-Marie Mes-Masson ${ }^{1,5, *}$
}

1 Centre de recherche du Centre hospitalier de l'Université de Montréal (CR/CHUM), Institut du cancer de Montréal, 1560 Sherbrooke Est, Montreal, H2L4M1, QC, Canada;

E-Mails: cecilelepage@yahoo.ca (C.L.P.); diane.provencher.chum@ssss.gouv.qc.ca (D.M.P.)

2 Department of Pathology and Genetic Pathology Evaluation Centre of the Prostate Research Center, Department of Pathology and Laboratory Medicine, University of British Columbia, Vancouver General Hospital, Vancouver, Canada; E-Mail: dhuntsma@bccancer.bc.ca (D.G.H.)

3 Translational and Applied Genomics, BC Cancer Agency, Room 3427, 600 West 10th Avenue, Vancouver, V5Z 4E6, BC, Canada

4 Département d'Obstétrique et Gynécologie, Clinique de Gynécologie Oncologie, Université de Montréal, 1560 Sherbrooke Est, Montreal, H2L4M1, QC, Canada;

E-Mail: diane.provencher.chum@ssss.gouv.qc.ca

5 Département de Medicine, Université de Montréal, 1560 Sherbrooke Est, Montreal, H2L4M1, QC, Canada

* Author to whom correspondence should be addressed;

E-Mail: anne-marie.mes-masson@umontreal.ca; Tel.: +1-514-890-8000 ext 25496;

Fax: +1-514-412-7703.

Received: 8 March 2010; in revised form: 19 April 2010 / Accepted: 13 May 2010 /

Published: 26 May 2010

\begin{abstract}
Epithelial ovarian cancer is the most lethal gynecological malignancy. Due to its lack of symptoms, this disease is diagnosed at an advanced stage when the cancer has already spread to secondary sites. While initial rates of response to first treatment is $>80 \%$, the overall survival rate of patients is extremely low, mainly due to development of drug resistance. To date, there are no reliable clinical factors that can properly stratify patients for suitable chemotherapy strategies. Clinical parameters such as disease stage, tumor grade and residual disease, although helpful in the management of patients after their initial surgery to establish the first line of treatment, are not efficient enough. Accordingly, reliable markers that are independent and complementary to clinical parameters are needed
\end{abstract}


for a better management of these patients. For several years, efforts to identify prognostic factors have focused on molecular markers, with a large number having been investigated. This review aims to present a summary of the recent advances in the identification of molecular biomarkers in ovarian cancer patient tissues, as well as an overview of the need and importance of molecular markers for personalized medicine in ovarian cancer.

Keywords: gynecologic cancer; outcome; immunohistochemistry

\section{Introduction}

Although epithelial ovarian cancer (EOC)s could originate either from normal ovarian surface epithelium (NOSE) itself or from the crypts or inclusion cysts arising from this surface epithelium [1], recent evidence suggests that high grade serous ovarian cancer can arise from the fallopian tube [2]. Even though the etiology of most EOCs is unknown, about $10 \%$ have been attributed to known genetic factors such as BRCA1 and BRCA2, or true mutations in mismatch repair genes such as MLH1 and MSH2, which causes predisposition to the Lynch syndrome [3]. Ovarian cancer is surgically staged using the FIGO classification, which is based on the volume and extent of tumor spread. Stage I tumors are limited to one or both ovaries. Stage II tumors are associated with pelvic extension. Stage III tumors are characterized by spreading outside the pelvis into the abdominal cavity or true retroperiteonal lymph node, and stage IV tumors present with liver parenchymal metastasis and/or distant metastasis. EOC is also graded according to the degree of differentiation: borderline or low malignant potential (LMPs) represent minimal deviation from their benign counterpart while well differentiated tumors are grade I, moderately differentiated are grade II, and poorly differentiated are grade III carcinomas. As this three part grading system for carcinomas was not reproducible, it has been replaced by a two category system with low and high grade carcinomas.

When the two category grading system is combined with histotype, the emergent classification system includes: serous (low grade and high grade), clear cell endometrioid, mucinous, and other rare types such as Brenner or undifferentiated [4,5]. The frequency of these subtypes in North America are high grade serous (HGS) cancer (70\%), clear cell carcinomas (12\%), endometrioid (11\%) and finally low grade serous (LGS) and/or mucinous carcinomas $(<5 \%)$. Although all of these subtypes are distinct in terms of their association with precursor lesions, risk factors and mutation profiles, the high grade serous cancers feature near universal p53 mutations and genomic instability whereas low grade serous cancers, endometrioid carcinomas, mucinous carcinomas and clear cell carcinomas have relatively stable genomes and rare tp53 mutations. High grade serous tumors show particular differences in terms of their development, genetic alterations and prognosis. This has led to the classification of ovarian cancer into two types: type 1 tumors, which are low grade and slowly developing (endometrioid, mucinous and low grade serous tumors), and type 2 tumors, which rapidly progress (high grade serous). In addition, the association of biomarker expression with survival varies substantially between subtypes, and can easily be overlooked in whole cohort analyses. Although these data suggest substantial differences between subtypes, until recently ovarian carcinomas were typically approached as a monolithic entity by researchers and clinicians. This practice impeded progress in 
understanding the biology or improving the management of the less common ovarian carcinoma subtypes. To avoid this effect, each subtype within a cohort should be analyzed individually. Therefore, molecular classifiers of ovarian cancer are of high clinical relevance in the management of these cancer patients.

Over the last 15 years, the Gynecologic Cancer InterGroup GCIC, a cooperative of 16 international groups interested in the treatment of gynecologic cancer, has made an international effort to coordinate research and practice in the treatment of ovarian cancer, including therapy and prognosis factors [6]. The standard treatment for ovarian cancer patients is cytoreductive surgery, during which adequate staging is performed. Clinically, the most important prognostic factor is the presence of residual disease after initial de-bulking surgery.

This treatment is followed by a platinum-based combination of chemotherapy, although the disease will recur and inevitably become resistant to further chemotherapy (reviewed in [7]). Two platinum compounds are in common use, cisplatin and carboplatin, with slightly different spectra of activity [8]. Carboplatin in combination with taxane is often chosen as a treatment following surgery for most stages of ovarian cancer [9]. For select patients with stage III EOC, intraperitoneal chemotherapy has become one of the standard options, but due to toxicity and health resource issues this has not been universally adopted. Currently, patients, disease and health care resources are important parameters when choosing therapeutic options [10].

While more than $80 \%$ of the patients will initially respond to treatment, recurrence is common but is generally observed within variable time intervals. Patients recurring within six months of first line treatment are considered as resistant, while recurrence at 6-24 months is considered a moderate response and greater than 24 months is considered a good prognosis. The high rate of recurrence and mortality of this disease $(>80 \%)$ underscores the need for a greater understanding of the molecular basis of the disease and the development of new clinical tools for the detection and management of ovarian cancer patients.

Without doubt, the age of personalized medicine is at our doorstep. In concrete terms, personalized cancer care has several goals that impact our society and the care of patients. In particular, before cancer is detected it should be possible, based on genetic and environmental factors, to estimate an individual's risk for developing a particular cancer. Here the alteration of modifiable risk factors, and the close monitoring of high-risk individuals, should be attainable goals and risk-reducing strategies. Once diagnosed, personalized medicine means matching each cancer patient to the most appropriate treatment. This not only results in superior medical care, by improving effectiveness while diminishing toxicities, but it also impacts directly on health economics and quality of life issues. Finally, future clinical research, coupled to companion translational research studies, should inevitably improve performance at an individual level. This review focuses on molecular markers associated with patient outcome and provides a summary of studies identifying potential biomarkers for EOC (refer to supplementary file).

\section{Protein Biomarkers Associated with Chemoresistance and Survival}

More than a thousand publications have identified potential prognostic markers of epithelial ovarian cancer. However, most of these proposed markers have an uncertain clinical value, their independent 
prognostic significance is unclear and none are used clinically. In this review, we introduce and discuss the main groups of biomarkers identified by immunohistochemistry.

\subsection{Oncogenes and Tumor Suppressors}

\subsubsection{Tumor Suppressor p53}

Although the oncoproteins p53 and Her-2 are among the most investigated markers in ovarian cancer, they have still not shown reproducible results in different studies (reviewed in [11] and supplementary file). The p53 protein is the most studied tumor suppressor, and mutations in the p53 gene and subsequent gene product have been related to most cancer types. De Graeff et al. [11] recently determined a prognostic value of p53 in ovarian cancer through a meta-analysis of 62 previously published studies using a total of 9448 patients. The authors also included a quality study assessment when performing their meta-analysis in order to help in evaluating and better understand the discordance between studies. The p53 status was analysis by IHC or mutational analysis. Out of 62 studies, 25 reported an association with poor survival while four were associated with improved survival. When the meta-analysis was restricted to serous tumors only, there was a significant association with poor prognosis. Although, histotype heterogeneity and chemotherapeutic treatment were not taken into account, a meta-regression analysis showed that the FIGO stage may influence the outcome predictive value of p53 and the prognostic significance of p53 seems also to be more restricted to low stage tumors [11]. Some other studies suggest a correlation between p53 status and response to platinum-based chemotherapy while strong discrepancies are noticed in clinical studies with paclitaxel-based treatment (reviewed in [12,13] and supplementary file). The apparent inconsistencies are likely due to different antibodies utilized, chemotherapeutic regimen and heterogeneity of histosubtypes, which render the interpretation of all these studies difficult.

\subsubsection{Wilms Tumor: WT1}

The Wilms Tumor gene (WT1) product was initially defined as a tumor suppressor gene involved in the development of Wilm's tumor, but today it is considered capable of performing oncogenic functions. In studies describing WT1 expression in ovarian cancer, there seem to be differences in expression patterns among different histological subtypes with higher expression in the serous subtype [14-17]. Conflicting reports show either no prognostic value, or a significant unfavorable prognosis associated with WT1, when all histological subtypes or all grades of serous tumors are analyzed [14-16,18-20], while WT1 becomes a favorable marker in a restricted high grade serous cohort of patients [16,21]. However, it is not an independent marker of survival in multivariate analysis. WT-1 is very useful as a diagnostic marker for tumors with serous differention and can be used to differentiate high-grade serous cancers from mixed carcinomas and all prognostic effects are likely due to association with serous tumors [16]. 


\subsection{Proliferation Markers}

\subsubsection{Ki67}

Numerous markers of interest under investigation in this group, which include Ki67, show contradictory observations [22-31] (supplementary file). Ki67 is the most studied proliferation marker in cancer research. It is a nuclear protein expressed in cells during the G1, S, G2 and M cell cycle phases and is absent in quiescent cells (phase G0). Ki67 is overexpressed in malignant tissues compared to benign or borderline tissues [32]. This overexpression seems to be correlated with the serous subtype [16,33] although the difference is not significant in all studies [30-32]. In most reports, high expression of Ki67 is associated with a poor patient outcome, either shorter survival or shorter disease-free survival [28,31-42] although not in all cases [16,30,43,44]. Interestingly, Kobel et al. [16] observed a significant association of Ki67 in a cohort of patients representing several histosubtypes of the disease but no association was observed when each subtype was individually analyzed. This result may explain some level of discrepancies between studies. However, in other studies including only serous patients an association between $\mathrm{Ki} 67$ and outcome was still observed [26,38,42] while in studies including several histological subtypes no association was observed [30,45] suggesting that other variables influence the predictive value of Ki67. Such variables may be related to treatment regimens which often varies between studies.

\subsubsection{Proliferation Cell Nuclear Antigen or PCNA}

PCNA is a protein cofactor of DNA polymerase during DNA replication. Ki67 is considered to be a more indicative proliferation marker than PCNA, and consequently PCNA is less frequently used. Using the monoclonal PC-10 antibody from DAKO Inc., no correlation has been observed between PCNA nuclear expression and survival of ovarian cancer patients [28,46] (Refere to Supplementary file). However some investigators showed a poor outcome in patients with highly proliferative ovarian cancer tissues [12,47,48] while other authors, analyzing a cohort of 92 patients, reported a better five-year survival in tissues with higher PCNA staining [49]. Interestingly, some investigators that have analyzed both Ki67 and PCNA in the same cohort of patients showed a concordant result with both markers $[28,46,47]$. This suggests that the significance of proliferation markers and outcome of patients is more dependent on the selected patient cohort than the proliferation marker chosen. In the same line of evidence, Nijman et al. [50] reported the influence of platinum-based chemotherapy on the increased expression of molecular markers such as p53 and PCNA.

\subsubsection{Topoisomerases}

Another set of proteins involved in cellular proliferation are topoisomerases. Topoisomerases are enzymes that alter the topologic states of DNA. In particular, Topoisomerase II (Topo II) catalyzes the relaxation of supercoiled DNA during DNA replication. Topo II is a marker of proliferation, expressed during the G1, S, G2 and M phases of cell cycle but absent during the resting Go phase. In addition, Topo II is also the molecular target of the chemotherapeutic agent etoposide and in cells treated with etoposide DNA breaks accumulate and trigger cell death. Topo II has been described as a marker for 
platinum-based chemotherapy sensitivity and is associated with shorter survival [39,51-53] (Refer to Supplementary file). It remained an independant variable in a multivariate analyses of survival [39,54]. However, it has not been described as a marker of platinum chemotherapy sensitivity in every study [54-56]. The discrepancy is likely due to differences in study design.

\subsection{Cell Cycle Regulators}

There is strong evidence in the literature that cell cycle regulators are involved in ovarian cancer progression and can modify response to treatment. Cyclins are a family of proteins that control cell cycle progression by activating cyclin-dependent kinase (Cdk) enzymes (Figure 1). The cyclin-Cdk complexes are, in turn, regulated by kinase inhibitors, termed CKIs. Cyclins are expressed and then disappear at specific time points during the cell cycle. CyclinD/CDK4/6 and CyclinE/CDK2 regulate the transition from $\mathrm{G} 1$ to $\mathrm{S}$ phase of the cell cycle. They mediate the phosphorylation and inactivation of $\mathrm{Rb}$, thus permitting cell cycle progression. Cyclin A interacts with $\mathrm{Cdk} 2$ at the late GI and S phase and form a complex essential for the entry in mitosis. The cell cycle is then regulated by two major families of CKIs. The INK4 family, which includes p14, p16 ${ }^{\text {Ink4A }}$ and p18, inhibits Cyclin D/CDKs. The Cip/kip family, which includes p2 $1^{\text {waf1 }}$, p2 $7^{\text {kip1 }}$ and p57, inhibits Cyclin E/CDK. Cell cycle deregulation leading to oncogenesis can be caused by aberrant expression of positive regulators (cyclins) or loss of negative regulators (CKIs).

Figure 1. Brief schematic representation of cell cycle regulation.

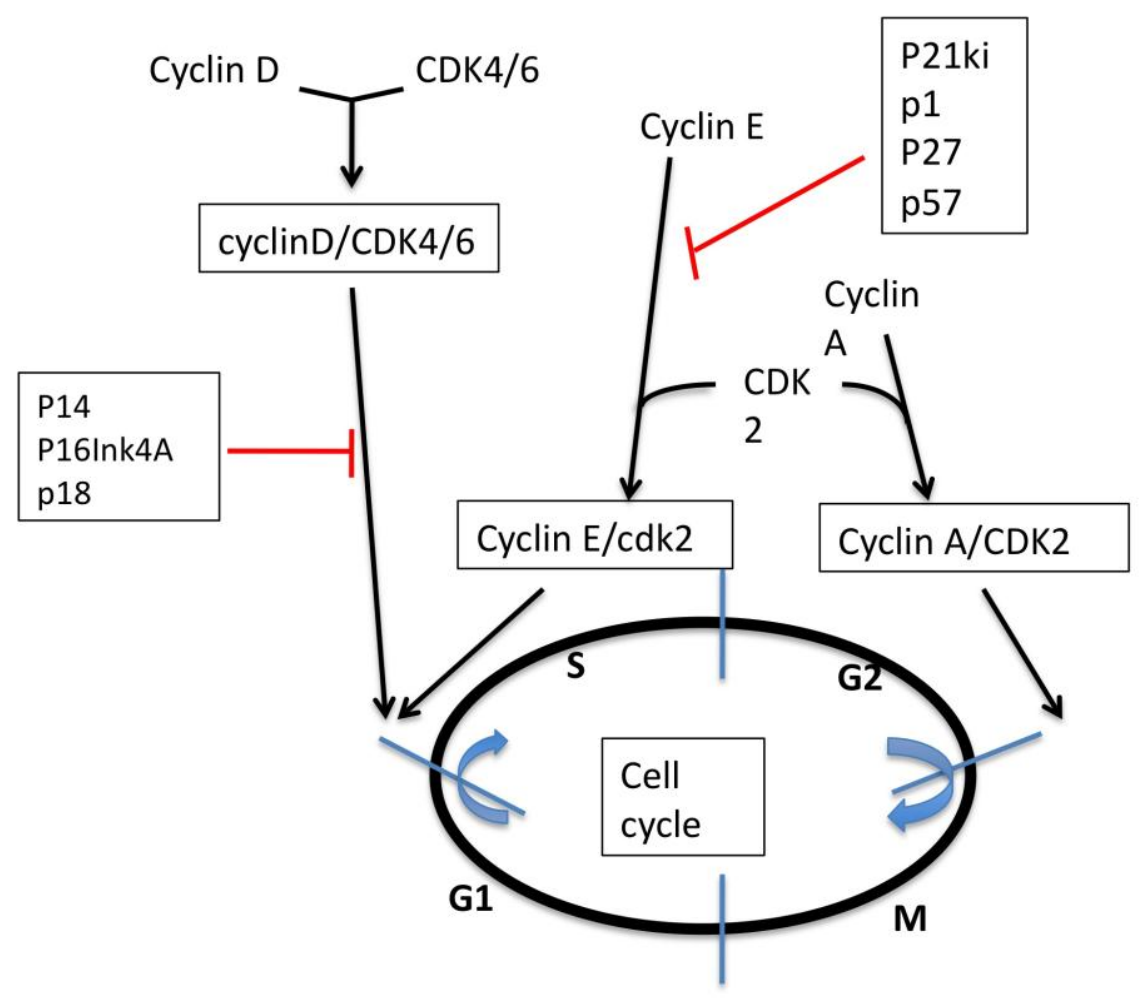

\subsubsection{Cyclins}

Cyclin $\mathbf{E}$ is the most studied cyclin in EOC and is associated with poor prognosis in patients with serous EOC and in cohorts with a large majority of the serous subtype [57-62] (reviewed in [63] and 
Supplementary file), but not in non-serous cohorts [57] or tissue sets from patients with a minority of serous disease [41]. Surprisingly, Bedrosian et al. [62] showed that cyclin E expression is associated with overall recurrence but not with response to platinum-based chemotherapy (recurrence before six months). Studies that included non-chemonaive patients did not observe an association between overall survival and cyclin E [30,62,64] suggesting that the chemotherapeutic treatment may impact cyclin E expression and cell cycle regulation. In some multivariate studies including a majority of serous samples, cyclin $\mathrm{E}$ is an independent variable of prognosis [60,61]. Interestingly, cyclin $\mathrm{E}$ is less expressed in serous tissues than other histosubtypes [57,61] which again suggests that the prognostic value of cyclin E should be analyzed in individual EOC histosubtypes. Indeed, it is likely that complex mechanisms contribute to loss of cell cycle control among these different histological subtypes [30]. Nevertheless, cyclin E is a promising biomarker candidate of ovarian cancer outcome, since it has shown the most reproducible results compared to other candidates.

Cyclin D1 expression has been linked to poor patient outcome, however some studies also reported no association with outcome in serous cohort of patients (review in [12], Supplementary file). Cyclin D1 expression is not related to disease features such as stage, grade, or histopathology [64,65]. In high stage disease (III and IV) an association between cyclin D1 protein expression and patient survival has been reported $[64,66]$. Studies using cohorts with mixed subtypes of EOC did not support a relationship between survival and cyclin D1 expression [57,65-67,247].

Cyclin D3 was determined to be a prognostic marker in a reported study of 82 patients, representing different histologic subtypes, grade and stages of the disease [68]. In contrast to cyclin D1 and cyclin $\mathrm{E}$, the presence of cyclin D3 was reported to be associated with better patient survival (110 months compared to 22 months in patients with no expression of cyclin D3).

Cyclin A has been found to be overexpressed in some ovarian tumors, however overexpression and assocation with patient survival remains controversial, mainly due to the limited number of patients and lack of well defined quality criteria in these studies. In a cohort of 31 patients, Yoons et al. [69] reported an association between high expression of cyclin A and poor three-year survival rates. On the other hand, Davidson et al. [70] reported a better overall survival of patients with high expression of cyclin A in effusion samples of high stage disease. The differential expression of cell cycle regulators is also linked to the histopathological type of the EOC (review in [71] and Supplementary file). An association of cyclin A and patient survival of patients has been observed in endometrioid tissues but not in serous tissues [72]. New studies are required to clarify the significance of cyclin $A$ as a prognostic indicator of ovarian cancer.

\subsubsection{Cyclin Inhibitors: p21, p27, p57 and p16}

The activity of cyclin $\mathrm{E}$ is inhibited by the cyclin inhibitors $\mathrm{p} 21^{\mathrm{Waf} 1 / \mathrm{CIP} 1}, \mathrm{p} 27^{\mathrm{Kip} 1}$ or $\mathrm{p} 57^{\mathrm{kip} 2}$ while the activity of cyclin D is inhibited by $\mathrm{p} 16$. The negative regulation of cyclin D or E leads to cell cycle arrest in G1 phase. The predictive value of $\mathrm{p} 21^{\text {Waf1 }}$ and $\mathrm{p} 27^{\mathrm{Kip} 1}$ have been analyzed in ovarian cancer patients (reviewed by [12]). In serous tumors, positive $\mathrm{p} 27^{\mathrm{Kip} 1}$ staining is significantly higher in early stage than that in advanced stage disease ( $\mathrm{p}=0.03$, Fisher's exact test). In several studies, Kaplan-Meier curves and log-rank testing showed that absence or low p2 $7^{\text {Kip } 1}$ expression significantly correlates with poor survival of patients in univariate or multivariate analyses $[32,59,64,73-76]$. In 
contrast, Schmider-Ross et al. [76] reported, in a cohort of 165 patients, that high $\mathrm{p} 27^{\mathrm{Kip} 1}$ expression is associated with longer disease-free progression, but that this marker did not predict responses to either taxol- or platinum-based chemotherapy. Similar results were found in a cohort of 185 patients with advanced stage disease [77]. However, an association between $\mathrm{p} 27^{\mathrm{Kip} 1}$ and chemotherapy response was not observed in other studies including all grades, stages and histopathologies [62,78]. Interestingly, Rosen et al. [79] also analyzed the cytoplasmic expression of $\mathrm{p} 27^{\mathrm{Kip} 1}$, instead of the usual nuclear expression, which represents the inactive status of $\mathrm{p} 27^{\mathrm{Kip} 1}$. The authors reported a strong correlation with shorter disease-specific survival.

A number of studies have reported controversial results (see review in [12] and Supplementary file) about the prognostic value of $\mathrm{p} 21^{\text {Waf1 }}$. The $\mathrm{p} 21^{\text {Waf1 }}$ protein was either reported to be associated [30,45,64,80-83] or not to patient survival or chemotherapy response $[16,35,77,84,85]$. Since wild-type p53 regulates the transcription of the p21 gene, the protein level of p53 may influence the level of $\mathrm{p} 21$ and account for the prognostic value of $\mathrm{p} 21^{\text {Waf1 }}$. A correlation between $\mathrm{p} 53$ and p21 Waf1 expression was observed in most [35,64,78] but not all studies [82-84]. In addition, the prognostic value of $\mathrm{p} 21^{\text {Waf1 }}$ was reported to be dependent on wild type expression of p53 [78,80,84], which may explain some of the discrepancies between previous analyses. Altogether, the prognostic significance of $\mathrm{p} 21^{\mathrm{Waf} 1}$ in ovarian cancer still remains unclear.

Few studies have reported the association of $557^{\text {kip2 }}$ and the prognosis of ovarian cancer patients. Sui et al. analyzed 47 patients with malignant ovarian cancer and found a significantly lower survival rate associated with low p57 $7^{\text {kip2 }}$ expression [86]. However, this result was not reproduced in two other studies that included a larger number of patients [22,57].

Consistent with the association between cyclin D1 and poor outcome observed in some studies, the loss of $\mathrm{p} 16^{\mathrm{Ink} 4 \mathrm{~A}}$ protein expression has also been linked to a reduced five-year survival rate in a study analyzing 300 ovarian cancer patients of mixed subtypes treated with palictaxel and platinum [87] as well as in a smaller cohort of 43 patients [88]. However, in the subgroup of optimally debulked patients, $\mathrm{p} 16^{\mathrm{Ink} 4 \mathrm{~A}}$ was no longer associated with the rate of patient survival [87]. Even if no correlation was observed between the expression of p16 and FIGO stage [65,87,89], p16 loses its significance as a prognostic variable in tumors of high stage disease [30,64,88]. Conversely, p16 expression has also been linked to a worse prognosis in patients [22,90,91]. Although puzzling, Dong et al. observed an inverse prognostic value comparing stromal and epithelial p16 expression [91]. In the stromal cells from 159 ovarian tumor tissues from patients presenting a range of grades, stages and histopathologies, high p16 expression was associated with a better overall survival while high expression in tumor epithelial cells is linked to a shorter survival.

\subsection{Apoptosis}

Apoptosis is programmed cell death chracterized by specific cellular and morphological changes. These changes are mediated by two major pathways, both leading to the release of cytochrome $\mathrm{c}$ and the activation of caspases, a family of cysteinyl aspartate-specific proteases. The extrinsic pathway is initiated by external stimuli, such as TRAIL, TNF (Tumor Necrosis Factor) and Fas-L, while the intrinsic pathway is initiated by intracellular signaling events such as p53 and Bcl-2 family protein activation (Figure 2). 
Figure 2. Brief schematic representation of intrinsic and extrinsic apoptotic pathways.

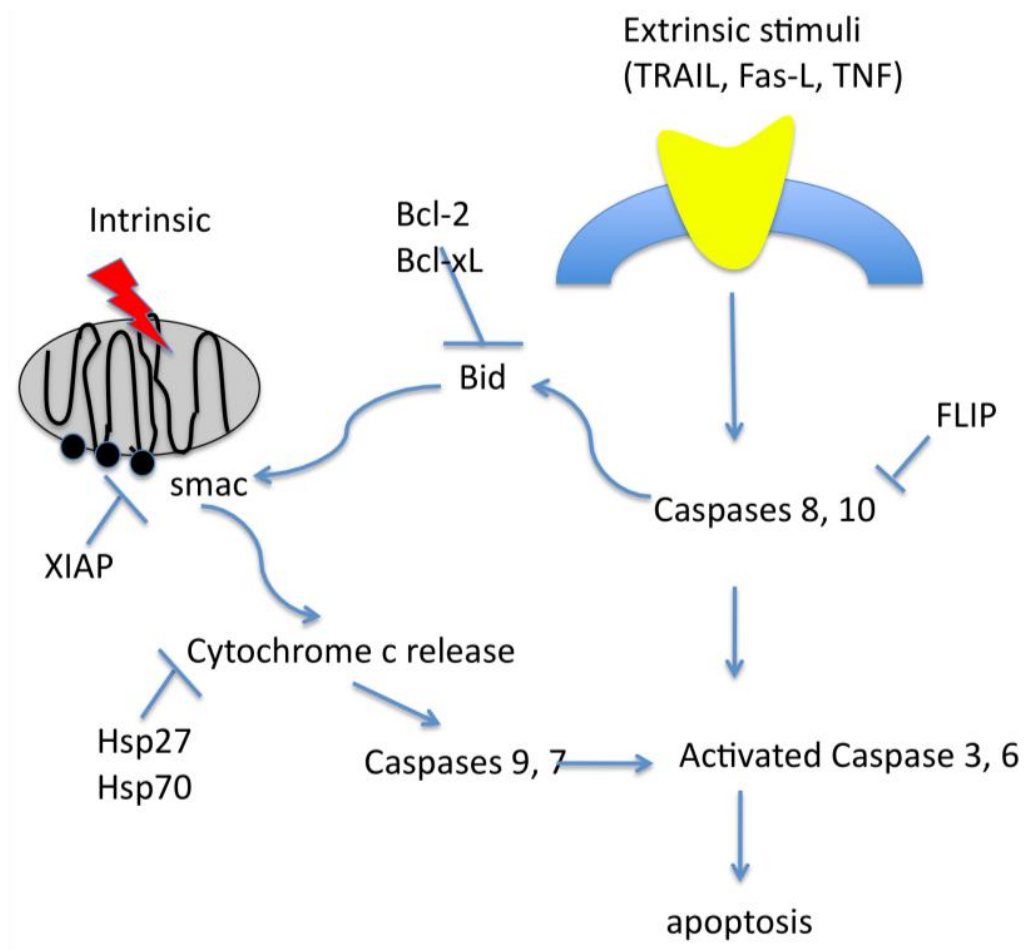

\subsubsection{Extrinsic Apoptotic Pathway}

\subsubsection{TRAIL and Receptors}

TRAIL, TNF Related Apoptosis Inducing Ligand, is an extracellular protein that triggers apoptosis through binding to a family of membrane receptors leading to the activation of caspase 8 and 3. Two categories of TRAIL receptors exist. TRAIL-R1/DR-4 and TRAIL-R2/DR-5 belongs to the first category and contain a death domain capable of inducing apoptosis while TRAIL-R3/DcR1, TRAIL-R4/Dcr2 and TRAIL-R5, also called decoy receptors, lack a functional death domain. Expression of different combinations of TRAIL receptors has been shown to enhance the cellular killing abilities of TRAIL in a variety of cell lines (review in [92] and Supplementary file). TRAIL is expressed in tumor and stromal cells. Only in high stage (III-IV) patients is the presence of stromal TRAIL significantly associated with survival in univariate and multivariate analysis [93]. However, even if no differential expression was reported between pre-and post- treated samples, the association between TRAIL and survival was not observed in platinum-treatment patients with either high stage or low stage disease [94]. In a restricted analysis of serous patients, Ouellet et al. also reported the absence of any significant association between TRAIL and disease-free survival at 18 months [58]. Since TRAIL-induced apoptosis can be regulated at the level of receptor and decoy receptor, evaluation of TRAIL and its receptors has also been done but no receptor was associated with patient prognosis $[58,93]$.

TRAIL-induced apoptosis is also regulated by the cellular FLICE inhibitory protein (FLIP), which can block caspase- 8 cleavage due to their structural similarities. Two forms of FLIP, named FLIPs and FLIP(L), have been identified to date, both of which contain two death domains. The level of stromal 
or tumoral FLIP alone does not show an association with survival rate of patients $[58,93,94]$, but in concert with Dr4, Dr5 or p53, low levels of FLIP(L) correlates with a worse patient prognosis $[58,95]$.

\subsubsection{Fas and Fas-L}

The Fas (CD95) family of cell surface receptors initiates an apoptotic pathway through interaction with FasL. Upon activation, the Fas receptor trimerizes and interacts with FADD to form the death inducing signaling complex (DISC), which drives downstream events leading to the activation of caspase 8 and caspase 10. Very little information is currently available for Fas and Fas-L in ovarian cancer cells. A study of 35 ovarian carcinomas showed that Fas-L is overexpressed compared to benign or borderline tumors, and surprisingly, this overexpression was linked to a poorer five-year survival rate. However, due to the very limited number of patients studied, this observation needs to be reproduced in larger patient cohort [96]. In 75 peritoneal and pleural effusions, Dong et al. [97] also observed that tumor cells expressing high levels of Fas conferred a poor response to chemotherapy, including platinum treatment, in ovarian cancer patients, but was not associated with disease-free progression survival or overall survival. In contrast, platinum-based chemotherapy treatment reduces Fas expression levels [94]. The presence of Fas in tissues obtained after platinum treatment correlates with disease stage and longer disease-free and overall survival, but not in multivariate analyses [94].

\subsubsection{Intrinsic Apoptotic Pathway}

\subsubsection{The Bcl-2 Family Members}

Defects in apoptotic pathways can result in reduced sensitivity to chemotherapeutic drugs. Expression of the gene products involved in pro- and anti-apoptotic pathways have been implicated in patient outcome and drug resistance in ovarian cancer. This includes p53, which enhances cell death through regulation of the Bcl-2 protein family. More than 20 members of the Bcl-2 family have been identified, including proteins that suppress (Bcl-2, Bcl-xL, Mcl-1, Bcl-W, Bcl-G) and proteins that promote (Bax, Bak, Bad, Bid, Bik, Bim, Bcl-xs) apoptosis. Diverse Bcl-2 family proteins are capable of physically interacting, forming homo- or hetero-dimers, a property critical for their ability to regulate each other.

Bax, a pro-apoptotic Bcl-2 member, leads to the release of cytochrome $\mathrm{c}$ and activation of caspase 9 and 3. In line with the in vitro evidence of the role of Bax, its expression has been associated with apoptosis in ovarian cancer tissues [98] and patients survival. In a cohort of 52 patients representing a range of histopathology and tumor grades, Schuyer et al. found that patients expressing high levels of Bax in tumors had a significantly longer median survival (57 months) than patients with low Bax expression (18 months) [85]. Similar results were obtained when the progression free survival was analysed. Interestingly, in a independent and larger cohort of 185 women with stage III disease, Bax was also associated with better survival [77] as well as in a cohort of 102 patients with early stage disease and post-treated with radiotherapy [99]. The relationship between p53 and Bax expression remains unclear. While most studies have not observed a correlation between Bax and p53 protein levels, [44,100-102] at least one study has reported such an association [98]. Bax was associated with survival of early stage patients in a p53 mutant subgroup but not in the p53 wild type subgroup [100]. 
In contrast, others observed better survival in patients with both high Bax and p53 protein accumulation levels [101]. On the other hand, Bax expression was associated with complete remission in 199 patients, but not when patients were separated into p53 mutant and p53 wild type subgroups [102]. Although the number of samples was very limited, it was noted that mucinous carcinomas showed the lowest rate of Bax staining while clear cell carcinomas had the highest rate $[98,99]$ suggesting that Bax should be analyzed separately in each histologic subtype.

Bcl-2 itself has in vitro an anti-apoptotic activity and has been inversely correlated with the level of apoptotic index in ovarian cancer tissues [98,103,104]. Paradoxically, some studies showed an improved survival in patients with high Bcl-2 expression [98B,104,105], and improved disease-free survival with high expression of Bcl-2 [98,101], in contrast to most studies that did not report a significant association between Bcl-2 expression in ovarian cancer tissues and prognosis $[20,44,80,85,96,100,102,106-112]$. Other conflicting results indicate that patients with high Bcl-2 levels show the lowest frequency of complete response to chemotherapy, and a shorter survival, when treated with platinum-based regiments [101,103,113].

$\mathrm{Bcl}-2$ and $\mathrm{Bcl}_{\mathrm{XL}}$ are homologous proteins and share similar functions as apoptosis suppressors. However, the expression pattern of these proteins is strikingly different and Bcl-2 has been more extensively studied as a molecular marker than $\mathrm{Bcl}_{\mathrm{XL}}$. The expression of $\mathrm{Bcl}_{\mathrm{XL}}$ increases after chemotherapy treatment [82,114], and this variable, although not always well detailed in published reports, may affect its prognostic value. Limited studies have linked $\mathrm{Bcl}_{\mathrm{XL}}$ to shorter disease-free progression but not to overall survival [77,82,110,113].

The other anti-apoptotic Bcl-2 familly members, such as Mcl-1, Bcl-W or Bcl-G have not been extensively investigated in ovarian cancer. No differential expression has been observed in malignant tumors compared to benign or normal tissues [115,116]. Positive staining of Mcl-1 in a cohort of 185 heterogenous patients displayed a significant association in univariate but not multivariate analyses of five-year survival rates [77], but this observation needs to be validated in independent studies.

\subsubsection{Caspases}

There are two categories of caspases: initiator or effector, depending or their role in the apoptotic signaling cascade. Caspase-3/CPP32, -6 and -7 are effectors while caspase- $8,-9$ and -10 are initiators. Activated caspase 3 coordinates the DNA fragmentation, which leads to cell death. Results reporting on the association of caspase 3 and the outcome of ovarian cancer patients are conflicting. In serous pleural and peritoneal effusions the level of cleaved caspase 3 and 8 correlated with improved progression free and overall survival although in multivariate analysis, only cleaved caspase 3 was an independent variable [117]. However, in serous primary solid tumors the level of cleaved caspase 8 is not associated with patient survival [58] and similarly, it appears to lose prognostic significance in samples obtained post-chemotherapy [94]. In contrast, one study has reported that caspase 3 was associated in both univariate and multivariate analyses with shorter disease-free progression and survival in 43 pre-chemotherapy and 36 post-chemotherapy patients with stage III disease [82]. 


\subsubsection{Inhibitor of Apoptosis: IAPs}

Inhibitor of apoptosis proteins (IAPs) are caspase inhibitors that prevent apoptosis by specifically inhibiting caspases 3, 7, and 9. This family of proteins contains eight members: cellular IAP1 (c-IAP1), cellular IAP2 (c-IAP2), neuronal apoptosis inhibitory protein (NAIP), Survivin, X-linked IAP (XIAP), Apollon, testis- specific IAP (Ts-IAP), and Livin. Livin is not expressed in ovarian cancer cells [118]. In ovarian cancer, Survivin is the best known member of the IAPs family. It is overexpressed in high-grade tumors compared to low grade tumors [110,118]. Nuclear expression was associated with better disease-free survival and overall survival in tumor cells from samples derived from 101 effusions. However, this association is lost in samples obtained after chemotherapy [118]. In contrast, in primary solid tumor samples, the expression of Survivin was associated with poor overall survival [119]. No information is available on the predictive role of the other IAP family members with the exception of XIAP, which in one study, including 101 patients with a majority of serous EOC subtype, was found to have no correlation with survival [118].

\subsection{Repair Enzymes: BRCA-1 and -2, PARP, ERCC1}

The polyADP-ribose polymerase 1 (PARP-1) is a repair enzyme involved in the single strand DNA break repair pathway and cell apoptosis, while BRCA-1 and -2 are involved in double strand break DNA repair by homologous recombination. So far, only one report has investigated the level of PARP expression and its association with response to standard chemotherapy in serous ovarian cancer patients [120].

Excision repair cross complementation (ERCC1) is a key protein in the excision of DNA adducts caused by platinum compounds. ERCC1 is expressed in less than $15 \%$ of EOC tissues analysed and increases after platinum treatment [121]. Positive staining of ERCC1 is associated with platinum-based chemotherapy resistance [121,122], shorter disease-free survival and with a trend for shorter overall survival [121]. Interestingly ERCC1 was still significantly associated within a multivariate analysis including age, disease stage, grade and residual disease. This study validates the association between ERCC1 mRNA expression and poor outcome of ovarian cancer patients observed in several other studies [123,124].

The role of BRCA-1 and -2 are most often investigated in the context of hereditary ovarian cancer, but recent reports also highlight the relatively high prevalence of somatic mutations in BRCA-1 and -2 genes and the potential use of individualized therapy for these patients [125-127]. In additon, evidence suggests a decrease in BRCA-1 protein expression with advancing stage as seen by immunohistochemistry [128]. In the same study of 230 patients, the decreased expression of BRCA-1 $(<10 \%)$ also correlated with the serous subtype, longer progression-free survival and longer overall survival [128]. However, this association was not seen in a smaller cohort of 87 Thai patients [129], therefore the potential of BRCA as a predictive marker in the general ovarian cancer population requires further investigation. 


\subsection{Markers of Angiogenesis}

\subsubsection{Markers of Microvascular Density}

Tumors secrete extracellular mediators that initiate the growth of blood vessels, thus allowing increased tumor vascularization. This process, named angiogenesis, has been associated with an unfavorable prognosis. In addition, inhibitors of angiogenesis have shown promise as therapeutics in ovarian cancer [130-132]. However, the complete clinical evaluation of these new agents and effective combinations of these agents with standard treatment for a particular disease are still lacking.

Angiogenesis assessment is often performed by immunohistochemistry with the method of Weidner et al. [133], where endothelial cell markers are stained to estimate microvessel density. In ovarian cancer, several reports have linked microvessel density and outcome in ovarian cancer. Although vessel density is heterogenous in tumor tissues, higher densities were observed in malignant tumors compared to borderline and in high stage tumors compared to low stage tumors [134,135]. A few additional markers, such as CD31, CD34, factor VIII and CD105, are also used to estimate angiogenesis. CD31/PECAM1 is expressed on circulating platelets and act as a major constituent of the endothelial cell junction. CD31 is the most commonly used marker in immunohistochemical analyses to assess microvessel density (also called MVD) and tumor angiogenesis in tissues. It is considered as a more specific marker of endothelial cells than factor VIII. Evaluation of MVD, as determined by CD31, has also led to largely contradictory results concerning the outcome of ovarian patients. In several studies, increased MVD compromised the overall survival in a cohort of late stage patients when high MVD was compared to low MVD [136-139]. Other studies, based on more limited cohorts of late stage disease, observed a better overall survival in patients with high MVD [140,141]. While no correlation between overall survival and MVD was found in 77 patients with stage I disease [142], the same authors showed that patients with high MVD had a shorter disease-free interval. In contrast to this result, when MVD was assessed with CD34, a better disease-free interval was observed in stage I patients with high MVD [143]. Evaluation of MVD, as determined by CD34, has also led to contradictory results [138,141,144-153]. Heterogeneity of ovarian tumors and measurement techniques may interfere with the assessment of the prognostic value of MVD in these tissues. In addition, the lack of methodology standardization, small and mixed cohort selection, and variation in treatment and outcome data make these studies very difficult to compare.

\subsubsection{Markers of Proteins Involved in Angiogenesis}

VEGF plays a major role in proliferation and migration of endothelial cells, thereby nourishing and favoring tumor growth. In tumor tissues, VEGF is expressed by epithelial tumor cells, stromal cells and macrophages [154]. It is significantly overexpressed in ovarian carcinomas as compared to benign or borderline tumors and this expression is inconsistently associated with disease stage and tumor grade [154-156]. In some studies, the survival rate of patients with high VEGF expression was worse than for patients with low or no VEGF expression [151,154-158] even in stage I patients [142]. This association remained significant in some multivariate analyses [154] but not in every study [155,156] and not in stage I patients [142]. In contrast, no association between VEGF expression in tissues and progression-free survival, response to chemotherapy or overall survival, was seen in cohorts composed 
of only cancer patients with advanced disease [143,159,160]. A larger study analyzing VEGF expression in 320 patients showed that patients with high VEGF expression in tumor tissues had a median survival of 24 months while patients with low VEGF expression had a median survival of 13 months [161]. Similar results were obtained by O'Toole in a cohort of 79 patients [162]. This association was also significant in the multivariate model including age, residual disease and stage. With respect to serum VEGF, a number of studies also reported an association with poor prognosis. These studies have been used in a meta-analysis pooling 314 patients and confirmed the relationship between high serum VEGF and poor overall survival [163]. Another study, which determined the level of VEGF in 39 ascites fluids, observed that high levels confer a shorter disease-free survival and overall survival than low levels [157]. In contrast, two studies were not able to reproduce the association between VEGF and survival of ovarian cancer patients. In a cohort of 112 patients VEGF was associated with better disease-free progression but not overall survival [152]. Similarly, western blot analysis of 67 high stage ovarian cancer tumors did not show any association between the level of VEGF, or its receptor, and outcome (disease-free progression or survival) of patients [159].

HIF, hypoxia-inducible factor, is a transcription factor involved in several cellular processes and is a key regulator of tissue hypoxia. It increases $\mathrm{O}_{2}$ availability and favors tumor growth and neoangiogenesis. It likely acts by increasing the expression of genes, such as VEGF and Nitric oxide synthetase, that regulate hypotoxic stress and angiogenesis (see Figure 3). HIF is overexpressed in ovarian cancer tissue as compared to benign tissue [149,164,165] and closly correlates with microvascular density of cancer tissues [149]. Among the different histological types of ovarian carcinoma, HIF is more highly expressed in clear cell carcinoma [165]. With the exception of one initial study [149], immunohistochemistry reveals that higher nuclear HIF-1 presence is associated with a poorer survival (45 compared to 70 months) in patient cohorts representing a range of histopathologies and stages, including advanced stage of serous disease [152,164,166]. This association remained significant in multivariate analysis [166]. In contrast, using a Western blot assay, it has been reported that in 52 patients with sub-optimally debulked stage III/IV EOCs, which were further treated with a combination of Taxol and Carboplatin, HIF-1 $\alpha$ expression correlated with significantly better survival [167] although this was not the case for the optimally debulked patients.

Figure 3. Role of hypoxia in tumor angiogenesis.

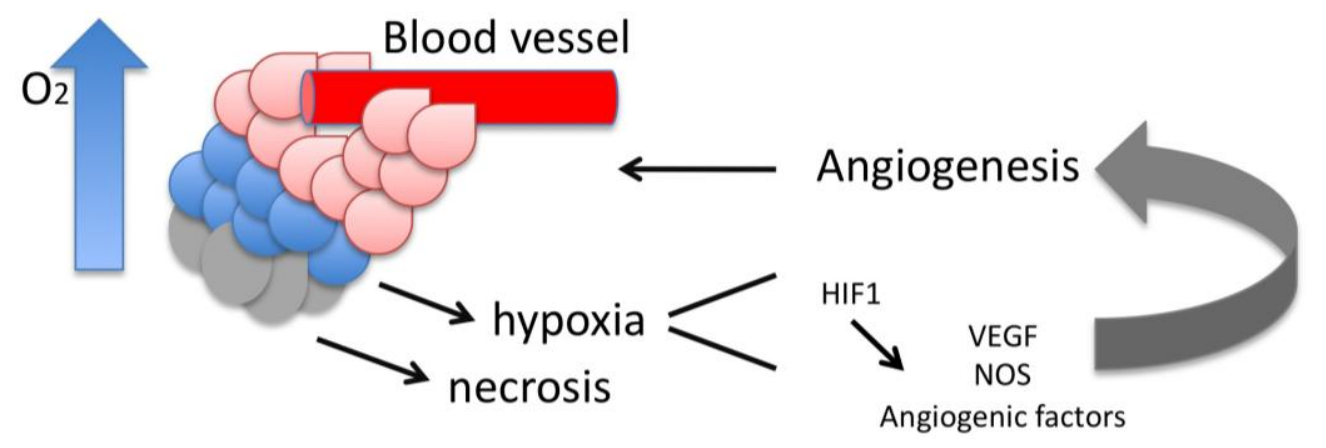


Cyclooxygenase-2 (COX-2), also known as prostaglandin-endoperoxide synthase-2, regulates prostaglandin synthesis and is involved in several cellular and biological processes, such as inflammation, apoptosis, proliferation, neoplastic effects, regulation of metalloproteinase and angiogenesis. Cox-2 is not expressed in normal ovarian epithelia [168,169]. In ovarian cancer tissues, Cox-2 expression positively correlates with the microvascular density of tumors $[150,151,170,171]$ confirming its role in angiogenesis of ovarian tumors. Most studies report an association between a poor prognosis in ovarian cancer patients and high Cox-2 expression [168-176]. Ali-fehmi et al. [170], who assessed 117 advanced stage serous ovarian carcinoma specimens from patients who did not received chemotherapy prior to surgery, reported that high Cox-2 expression is predictive of a short survival. This association was confirmed in a large study of 442 serous patients for which a five-year follow up was available [168]. Ferrendina et al. [177] observed such an association only in patients who underwent explorative laparatomy but not in patients that underwent primary debulking. In strong contradiction with all these results is another study analyzing 160 patients with long term follow-up (10 years), which reported a better survival rate in patients with high Cox-2 expression, and if correct suggests that Cox-2 may have different biological effects during the progression of the disease [178]. On the other hand, the expression and predictive value of Cox-2 differs between mucinous and non-mucinous tissues [169], which could be a variable influencing its predictive value. In addition, Cox-2 expression is not significant in all multivariate analyses reported [169,173].

Thrombospondin 1 (THBS-1) is a homotrimeric secreted glycoprotein with an anti-angiogenic effect. It acts by inhibiting neo-vascularization. In all studies except one [159], which included a mixed group of histopatholic types, THBS-1 was not related to survival [142,179,180], either in low stage patients or advance stage patients.

Metalloproteinase (MMP) regroups a large family of zinc- and calcium-dependent enzymes able to degrade the extracellular matrix and thereby facilitate invasion and metastatic spread [181]. A few studies have associated MMP expression with a poor prognosis in ovarian cancer (reviewed in $[12,182,183]$ and Supplementary file). In particular, MMP-9 was investigated in a large cohort of 292 EOC patients. High stromal expression of MMP-9 was associated with poor prognosis, although this association was not seen when comparing expression within tumor cells [184]. On the other hand, the tumoral expression of MMP-7 is an independent prognostic factor, predicting better survival and disease-free survial in ovarian cancer [185].

\subsection{Immunological Factors}

A large number of studies have reported an association between outcome and chemosensitivity of ovarian cancer patients and the presence of tumor-infiltrating immune cells or immunological factors. For example, the presence of $\mathrm{T}$ cells is associated with a good prognosis or chemosensitivity in ovarian cancer patients [186-194] while the presence of inhibitory T-Regs cells is often associated with a shorter survival [195-199], although not reproduced by all [200,201]. The survival rate of ovarian cancer patients has also been correlated with the presence of cytokines, co-stimulatory or inhibitory molecules expressed by immune cells or tumor cells [188,193,198,200,202-204]. For a detailed review see [193]. 


\subsection{Tyrosine Kinase Receptors (TKR)}

\subsubsection{Epidermal Growth Factor Receptors: ErbB}

One of the most studied tyrosine kinase receptor families is the epidermal growth factor receptor (EGFR). This family of proteins has been extensively studied in breast, lung, colon and prostate cancer and its members include EGFR/ErbB1, Her-2/ErbB2, Her-3/ErbB3 and Her-4/ErbB4. EGFR is more often related to poor survival of cancer patients, albeit unconsistently, while the ErbB2 prognostic significance remains uncertain. Similar results were obtained in ovarian cancer tissues (reviewed in [11,12] and Supplementary file). A recent meta-analysis of the literature using different studies including diverse patient cohorts concluded that EGFR and Her-2 have a limited influence on patient outcome, although their broad conclusion highlights the fact that studies need to be restricted to specific subtypes of ovarian cancer [11]. There are limited reports on the prognostic significance of ErbB3 and ErbB4 in ovarian cancer. ErbB3 expression was initially associated with a poor outcome in 28 endometrioid ovarian cancer patients [205] and more recently others reported a similar result in a cohort of 116 patients representing the range of histpathologies, stage and grade of the disease [206]. Although the study of Her-2 has not proven useful in most ovarian carcinoma subtypes, Her-2 overexpression and amplification can be seen in $20 \%$ of mucinous carcinomas and these cancers may respond to therapy targeting this TKR [207].

\subsubsection{Ephrin B receptors and other TKR}

More recently, the role of Ephrin (EPH) receptors has been investigated in ovarian cancer. The EPH receptors comprise a large family of TKR divided into the EphA and EphB subfamily, based on their sequence and structure. The activities of Eph receptors includes diverse cellular functions such as immune regulation, embryonic cell movement and tumorigenesis. In tumorigenesis, Eph receptors are suspected to promote angiogenesis, proliferation and invasion [208]. Particularly, EphB4 expression is confined to epithelial cells and has been reported to be expressed in EOC cells but not in normal ovarian epithelia [209]. High expression of Ephb4 is associated with poor reponse to chemotherapy in 72 patients with advanced stage disease [210], as well as poor survival rates in two independent cohorts including a range of EOC diseases [209,211]. Interestingly, EphB4 remains an independent variable in multivariate analysis [209]. While promising, these results need further investigation on a larger cohort of patients.

Similar to EGFR receptors, the high expression of hepatocyte growth factor receptor (Hgf/Met) and its ligand, c-Met, has been associated with a shorter overall survival of ovarian cancer patients [212,213].

\subsubsection{The Signaling Pathway of Tyrosine Kinase Receptors: Akt and NF- $\kappa B$}

Signaling pathways involved in apoptosis and cellular survival, such as Erk, Akt, PI3K, Akt, $\mathrm{NF}-\kappa \mathrm{B}$ have also been investigated for their potential association with the outcome of ovarian cancer patients [31,214-219]. Contradictory results have been reported. The PI3K/Akt pathway is a major signaling pathway activated by tyrosine kinase receptors. Activated Akt promotes downstream signaling involved in cell growth, proliferation and cell survival. In a recent study involving 63 patients, 
the presence of active/phosphorylated Akt was correlated with the presence of nuclear p65 and was associated with a lower rate of survival at five years [214]. The presence of active Akt was more significantly associated with reduced survival of patients as compared with the presence of nuclear p65 ( $\mathrm{p}=0.009$ and $\mathrm{p}=0.04$, respectively). The association between nuclear NF- $\kappa \mathrm{B}$ and poor survival was also observed in effusions from 166 patients [117]. However, the association between Akt and survival of ovarian cancer patients was not seen in previous studies [31,216,218]. Since these studies included either a limited number of patients and/or a range of pathologies, such studies need to be reproduced. Neither Akt nor NF- $\kappa \mathrm{B}$ were significant variables in multivariate analysis [117,214].

\subsection{E-cadherin/beta-Catenin}

Cadherins are type- 1 transmembrane glycoproteins involved in cell polarity and cellular adhesion ensuring cell adherence to tissues. Epithelial-cadherin (E-cadherin) is expressed by epithelial cells. Loss of E-cadherin results in increased cellular motility, the epithelial-mesenchymal transition and cancer progression. In EOC patients [220] as well as in serous cohorts of patients, E-cadherin downregulation is associated with poorer survival [221,222]. However, Voutilainen et al. [223] did not observe a significant association of E-cadherin with overall survival in a mixed range of histopathologies but they noticed a significantly better reponse to chemotherapy treatment. Interestingly, E-cadherin expression is less pronounced in clear cell and mucinous carcinomas [223], which may influence results towards a lack of prognostic significance in mixed patient cohorts.

The proper function of E-cadherin is regulated by its binding to catenin proteins. Binding of E-cadherin to catenins is essential for the maintenance of actin cytoskeleton and stabilizing cell-cell junctions. It is suspected that impaired function or expression of catenins may also be involved in ovarian cancer progression. Beta-catenin has been more studied that $\alpha$ - or $\gamma$-catenins. Furthermore, $\beta$-catenin is the target of Wnt signaling pathway. Wnt signaling results in phosphorylation of cytosolic $\beta$-catenin by Gsk-3 $\beta$ which leads to nuclear accumulation and trancriptional activation of target genes such as Cox-2 and cyclin D. The nuclear presence of $\beta$-catenin is significantly different among the histopatholgies of ovarian cancer [17,224] and also correlated to better survival of patients [220,224].

\section{Discussion}

For several years, efforts to identify reliable prognostic factors have focused on molecular markers. A large number of these markers have been investigated to date, usually by immunohistochemistry. Given the large number of potential candidate markers published (see Supplementary file for selected examples), it is remarkable that none have been approved for clinical use. Clearly, an overview of the literature shows that the determination of a common marker, or set of ovarian carcinoma markers identified in independent studies, has not been accomplished [225]. The focus on prognostic biomarkers may have been misplaced as other in very specific circumstances. Ironically, many markers published as having potential prognostic utility that are now questionable due to an association with subtypes, have proven to be useful as diagnostics to help subtype problematic cases (WT-1 in clear cell carcinoma and serous-mixed cancer) [21]. With recent clinical trial data showing potential utility for neoadjuvant therapy [8], a need for biomarkers to facilitate accurate subtyping from minimal tissue samples, i.e., FNA's or needle core biopsies, has emerged and many of the markers described above could prove to be useful for that purpose. 
Lack of reproducibility is a feature of most of these biomarker studies; this can be explained at least in part by technical and biological factors [225,226]. Two immediate explanations are apparent. Firstly, access to appropriate patients can be limited; most studies have analyzed only a small number of samples. Due to the inter-individual biological variability and heterogeneity of ovarian tumor tissues, results obtained on small sets of patients $(\mathrm{n}<100)$ are often not reproducible on larger sets of patients [227]. A second explanation is that most studies include heterogenous material with different histologic subtypes, different patient treatments, as well as different grades and stages of the disease. Since ovarian carcinoma subtypes are immunophenotypically distinct entities and have different clinical features such as stage at presentation and outcome biomarkers associated with a subtype, such as biomarkers expressed in serous epithelium, will have a predictable association in studies on mixed cohorts of ovarian carcinomas [16]. In addition, when biomarker data from cohorts with different proportions of subtypes are compared, one can reasonably expect that the association of biomarkers with outcome or stage at presentation can be expected to appear irreproducible [16].

Study quality is also a strong parameter influencing the inter-reproducibility of biomarkers analyzed. Studies should include inclusion and exclusion criteria, detailed tumor characteristics, selection of patients, follow-up time, additional treatments and specificity of the assay used. A particular technical challenge is the reproducibility associated with probing protein expression using specific antibodies raised against different epitopes. Some antibodies may recognize epitopes that are located in post-translationally modified regions of the protein and thus these epitopes are not expressed or detected in different conditions. In addition, most of the older studies did not verify the specificity of antibodies, thus raising the possibility that detection was non-specific. Such studies reported results that were sometimes difficult to reproduce with a different antibody, again suggesting a lack of specificity in the chosen antibody. Another important factor is the antibody titer. The use of the same antibody at different dilutions can give potentially very different results. A low concentration of antibody will quantitatively detect high expression of a marker by missing any low expression. Inversely, high antibody concentrations will quantitavely detected low expression but these same levels detect high expression but the result is not quantitative. The well described example is the antiHer-2 antibody [228]. Only low titers of anti-Her-2 will be able to identify patients with aggressive disease (high overexpression of Her-2).

The ability to construct tissue microarrays (TMA) has signaled a new area of high-throughput analysis to aid in the validation of tissue based biomarkers. A key benefit is the ability to analyse hundreds of patients at a time, reducing costs, time and increasing the reproducibility of results by staining the whole cohort simultaneously. However, these advantages come with a few pitfalls. Since the tissue analyzed by microarray are derived from small cores, the heterogeneity within a given tumor may influence the interpretation of results. Fortunately, in large cohort studies this sampling factor is reduced by the size of the sample set. In addition, since a TMA often contains hundreds of specimens collected over decades, the time between tumor collection and TMA construction may influence the antigenicity of certain biomarkers. Furthermore, during TMA construction, tissue oxidation may occur and induce a loss of antigenicity for some antibodies [229].

In addition to the aforementioned technical and study design problems associated with many immunohistochemical studies of ovarian carcinomas, a lack of transparency with and accountability for primary data from such studies may have contributed to the general lack of reproducibility. 
Fortunately it is now almost trivial to provide image archives from TMA and other studies to enable other researchers to calibrate and compare scoring systems. Tissue specimens can be analyzed with different systems ranging from pathologist image analyses to fully automated quantitative systems. Performing cross-platform comparisons should improve the reproducibility and validity of markers [230]. Finally, the lack of good quality control and guidelines [230] is often missing. Recent published guidelines for high standard biomarker discovery [231-234] will no doubt promote high quality studies and contribute to the greater reproducibility needed to validate clinically significant biomarkers.

Although the lack of currently usable tissue-based prognostic or predictive biomarkers for ovarian cancer may give little sense of optimism, this should change over the next few years. Firstly there is a recognition that ovarian carcinoma subtypes are distinct diseases and should be treated as such in research and ultimately in the clinic. Major discovery-based biomarkers studies are now typically subtype-specifc. For instance, The Cancer Genome Atlas Project (TCGA) has performed in-depth genomic analysis of high grade serous carcinomas and has recast our understanding of that disease. In addition to improved study methodology based on a subtype-specific focus, today's biomarker discovery research can include the decoding of ovarian cancer genomes at base-pair resolution. This approach, empowered by next generation sequencing technologies has already been used to identify a pathogenomic mutation in granulosa cell tumors and is now being applied to ovarian carcinomas [235,236].

There is a great need for diagnostic biomarkers for subtyping carcinomas, and predictive biomakers to identify women with high grade serous carcinomas who will not benefity from standard therapy. For the other subtypes, the development of new treatment approaches will demand the co-development of predictive biomarkers. These needs will only be met in a timely fashion if large clinically annoted cohorts are developed as communal resources for biomaker validation and if tissue banking and the collection of tumour blocks remeains a key priority in clinical trials.

While the present literature is replete with biomarkers, their true promise in changing clinical practice has not yet been realized. The most promising markers, as well as new candidates, will no doubt benefitfrom additional well-designed studies that would support their effectiveness and their usefulness in the clinical setting.

Recommendations for future studies:

- Consider EOC subtypes as different diseases for the purposes of biomarker studies.

- Clearly define and report the study cohort: inclusion and exclusion criteria for selecting patients, complete histopathology, stage and grade. Knowledge of treatment regimens is highly recommended. Recommendations addressing these points are provided by the NCI [231].

- Consider pitfalls of technology used for evaluation biomarkers: for tissue microarrays see [229].

- Apply high standard for study design, including a minimum number of patients, focusing on high statistical standard, see [232-234].

- Validation from independent investigators is an important criterion for determining the robustness of any given biomarker. 


\section{Acknowledgements}

The authors are very grateful to Luke Masson for critical review of the manuscript.

\section{References}

1. Auersperg, N.; Wong, A.S.; Choi, K.C.; Kang, S. K.; Leung, P.C. Ovarian surface epithelium: biology, endocrinology, and pathology. Endocr. Rev. 2001, 22, 255-288.

2. Levanon, K.; Crum, C.; Drapkin, R. New insights into the pathogenesis of serous ovarian cancer and its clinical impact. J. Clin. Oncol. 2008, 26, 5284-5293.

3. Lynch, H.T.; Casey, M.J.; Snyder, C.L.; Bewtra, C.; Lynch, J.F.; Butts, M.; Godwin, A.K. Hereditary ovarian carcinoma: heterogeneity, molecular genetics, pathology, and management. Mol. Oncol. 2009, 3, 97-137.

4. Gilks, C.B.; Prat, J. Ovarian carcinoma pathology and genetics: recent advances. Hum. Pathol. 2009, 40, 1213-1223.

5. Chuaqui, R.F.; Cole, K.A.; Emmert-Buck, M.R.; Merino, M.J. Histopathology and molecular biology of ovarian epithelial tumors. Ann. Diag. Patho.l 1998, 2, 195-207.

6. du Bois, A.; Quinn, M.; Thigpen, T.; Vermorken, J.; Avall-Lundqvist, E.; Bookman, M.; Bowtell, D.; Brady, M.; Casado, A.; Cervantes, A.; Eisenhauer, E.; Friedlaender, M.; Fujiwara, K.; Grenman, S.; Guastalla, J.P.; Harper, P.; Hogberg, T.; Kaye, S.; Kitchener, H.; Kristensen, G.; Mannel, R.; Meier, W.; Miller, B.; Neijt, J.P.; Oza, A.; Ozols, R.; Parmar, M.; Pecorelli, S.; Pfisterer, J.; Poveda, A.; Provencher, D.; Pujade-Lauraine, E.; Randall, M.; Rochon, J.; Rustin, G.; Sagae, S.; Stehman, F.; Stuart, G.; Trimble, E.; Vasey, P.; Vergote, I.; Verheijen, R.; Wagner, U. 2004 consensus statements on the management of ovarian cancer: final document of the 3rd International Gynecologic Cancer Intergroup Ovarian Cancer Consensus Conference (GCIG OCCC 2004). Ann. Oncol. 2005, 16 (Suppl. 8), viii7-viii12.

7. Itamochi, H.; Kigawa, J.; Terakawa, N. Mechanisms of chemoresistance and poor prognosis in ovarian clear cell carcinoma. Cancer Sci. 2008, 99, 653-658.

8. Mano, M.S.; Rosa, D.D.; Azambuja, E.; Ismael, G.; Braga, S.; D'Hondt, V.; Piccart, M.; Awada, A. Current management of ovarian carcinosarcoma. Int. J. Gynecol. Cancer 2007, 17, 316-324.

9. Muggia, F.M.; Fojo, T. Platinums: extending their therapeutic spectrum. J. Chemother. 2004, 16 (Suppl. 4), 77-82.

10. Muggia, F. Platinum compounds 30 years after the introduction of cisplatin: implications for the treatment of ovarian cancer. Gynecol. Oncol. 2009, 112, 275-281.

11. de Graeff, P.; Crijns, A.P.; de Jong, S.; Boezen, M.; Post, W.J.; de Vries, E.G.; van der Zee, A.G.; de Bock, G.H. Modest effect of p53, EGFR and HER-2/neu on prognosis in epithelial ovarian cancer: a meta-analysis. Br. J. Cancer 2009, 101, 149-159.

12. Gadducci, A.; Cosio, S.; Tana, R.; Genazzani, A.R. Serum and tissue biomarkers as predictive and prognostic variables in epithelial ovarian cancer. Crit. Rev. Oncol. Hematol. 2009, 69, 12-27.

13. Canevari, S.; Gariboldi, M.; Reid, J.F.; Bongarzone, I.; Pierotti, M.A. Molecular predictors of response and outcome in ovarian cancer. Crit. Rev. Oncol. Hematol. 2006, 60, 19-37. 
14. Hylander, B.; Repasky, E.; Shrikant, P.; Intengan, M.; Beck, A.; Driscoll, D.; Singhal, P.; Lele, S.; Odunsi, K. Expression of Wilms tumor gene (WT1) in epithelial ovarian cancer. Gynecol. Oncol. 2006, 101, 12-17.

15. Shimizu, M.; Toki, T.; Takagi, Y.; Konishi, I.; Fujii, S. Immunohistochemical detection of the Wilms' tumor gene (WT1) in epithelial ovarian tumors. Int. J. Gynecol Pathol. 2000, 19, 158-163.

16. Kobel, M.; Kalloger, S.E.; Boyd, N.; McKinney, S.; Mehl, E.; Palmer, C.; Leung, S.; Bowen, N.J.; Ionescu, D.N.; Rajput, A.; Prentice, L.M.; Miller, D.; Santos, J.; Swenerton, K.; Gilks, C.B.; Huntsman, D. Ovarian carcinoma subtypes are different diseases: implications for biomarker studies. PLoS Med. 2008, 5, e232.

17. Madore, J.; Fengge, R.; Filali-Mouhim, A.; Sanchez, L.; Kobel, M.; Tonin, P.N.; Huntsman, D.; Provencher, D.M.; Mes-Masson, A.M. Characterisaiton of the molecular divergence of ovarian endometrioid carcinoma and ovarian serous carcinoma. J. Pathol. 2009, 220, 392-400.

18. Hogdall, E.V.; Christensen, L.; Kjaer, S. K.; Blaakaer, J.; Christensen, I.J.; Gayther, S.; Jacobs, I.J.; Hogdall, C.K. Expression level of Wilms tumor 1 (WT1) protein has limited prognostic value in epithelial ovarian cancer: from the Danish "MALOVA" ovarian cancer study. Gynecol. Oncol. 2007, 106, 318-324.

19. Netinatsunthorn, W.; Hanprasertpong, J.; Dechsukhum, C.; Leetanaporn, R.; Geater, A. WT1 gene expression as a prognostic marker in advanced serous epithelial ovarian carcinoma: an immunohistochemical study. BMC Cancer 2006, 6, 90.

20. Yamamoto, S.; Tsuda, H.; Kita, T.; Maekawa, K.; Fujii, K.; Kudoh, K.; Furuya, K.; Tamai, S.; Inazawa, J.; Matsubara, O. Clinicopathological significance of WT1 expression in ovarian cancer: a possible accelerator of tumor progression in serous adenocarcinoma. Virchows Arch. 2007, 451, 27-35.

21. Kobel, M.; Kalloger, S.E.; Carrick, J.; Huntsman, D.; Asad, H.; Oliva, E.; Ewanowich, C.A.; Soslow, R.A.; Gilks, C.B. A limited panel of immunomarkers can reliably distinguish between clear cell and high-grade serous carcinoma of the ovary. Am. J. Surg. Pathol. 2009, 33, 14-21.

22. Khouja, M.H.; Baekelandt, M.; Nesland, J. M.; Holm, R. The clinical importance of Ki-67, p16, p14, and p57 expression in patients with advanced ovarian carcinoma. Int. J. Gynecol. Pathol. 2007, 26, 418-425.

23. Korkolopoulou, P.; Lazaris, A.; Konstantinidou, A. E.; Kavantzas, N.; Patsouris, E.; Christodoulou, P.; Thomas-Tsagli, E.; Davaris, P. Differential expression of bcl-2 family proteins in bladder carcinomas. Relationship with apoptotic rate and survival. Eur. Urol. 2002, 41, 274-283.

24. Mita, S.; Nakai, A.; Maeda, S.; Takeshita, T. Prognostic significance of Ki-67 antigen immunostaining (MIB-1 monoclonal antibody) in ovarian cancer. J. Nippon Med. Sch. 2004, 71, 384-391.

25. Tetu, B.; Popa, I.; Bairati, I.; L'Esperance, S.; Bachvarova, M.; Plante, M.; Harel, F.; Bachvarov, D. Immunohistochemical analysis of possible chemoresistance markers identified by microarrays on serous ovarian carcinomas. Mod. Pathol. 2008, 21, 1002-1010. 
26. Garzetti, G.G.; Ciavattini, A.; Goteri, G.; De Nictolis, M.; Stramazzotti, D.; Lucarini, G.; Biagini, G. Ki67 antigen immunostaining (MIB 1 monoclonal antibody) in serous ovarian tumors: index of proliferative activity with prognostic significance. Gynecol. Oncol. 1995, 56, 169-174.

27. Huettner, P.C.; Weinberg, D.S.; Lage, J.M. Assessment of proliferative activity in ovarian neoplasms by flow and static cytometry. Correlation with prognostic features. Am. J. Pathol. 1992, 141, 699-706.

28. Reitmaier, M.; Rudlowski, C.; Biesterfeld, S.; Rath, W.; Schroder, W.[Comparative studies on the biological significance of the marker for proliferation Ki-67-Antigen and PCNA in primary ovarian carcinoma]. Zentralbl. Gynakol. 2000, 122, 361-367.

29. Tomsova, M.; Melichar, B.; Sedlakova, I.; Nova, M.[Prognostic markers in ovarian carcinoma-retrospective study]. Cesk. Patol. 2005, 41, 51-59.

30. Milde-Langosch, K.; Hagen, M.; Bamberger, A.M.; Loning, T. Expression and prognostic value of the cell-cycle regulatory proteins, Rb, p16MTS1, p21WAF1, p27KIP1, cyclin E, and cyclin D2, in ovarian cancer. Int. J. Gynecol. Pathol. 2003, 22, 168-174.

31. Woenckhaus, J.; Steger, K.; Sturm, K.; Munstedt, K.; Franke, F.E.; Fenic, I. Prognostic value of PIK3CA and phosphorylated AKT expression in ovarian cancer. Virchows Arch. 2007, 450, 387-395.

32. Korkolopoulou, P.; Vassilopoulos, I.; Konstantinidou, A.E.; Zorzos, H.; Patsouris, E.; Agapitos, E.; Davaris, P. The combined evaluation of p27Kip1 and Ki-67 expression provides independent information on overall survival of ovarian carcinoma patients. Gynecol. Oncol. 2002, 85, 404-414.

33. Kritpracha, K.; Hanprasertpong, J.; Chandeying, V.; Dechsukhum, C.; Geater, A. Survival analysis in advanced epithelial ovarian carcinoma in relation to proliferative index of MIB-1 immunostaining. J. Obstet. Gynaecol. Res. 2005, 31, 268-276.

34. Garcia-Velasco, A.; Mendiola, C.; Sanchez-Munoz, A.; Ballestin, C.; Colomer, R.; Cortes-Funes, H. Prognostic value of hormonal receptors, p53, ki67 and HER2/neu expression in epithelial ovarian carcinoma. Clin. Transl. Oncol. 2008, 10, 367-371.

35. Sengupta, P.S.; McGown, A.T.; Bajaj, V.; Blackhall, F.; Swindell, R.; Bromley, M.; Shanks, J.H.; Ward, T.; Buckley, C.H.; Reynolds, K.; Slade, R. J.; Jayson, G.C. p53 and related proteins in epithelial ovarian cancer. Eur. J. Cancer 2000, 36, 2317-2328.

36. Goff, B.A.; Muntz, H.G.; Greer, B.E.; Tamimi, H.K.; Gown, A.M. Oncogene expression: longterm compared with short-term survival in patients with advanced epithelial ovarian cancer. Obstet. Gynecol. 1998, 92, 88-93.

37. Tomsova, M.; Melichar, B. Contribution of immunohistochemistry in prognostic assessment of epithelial ovarian carcinoma --review of the literature I. Acta Medica (Hradec Kralove) 2006, 49, 161-165.

38. Adams, S.F.; Levine, D.A.; Cadungog, M.G.; Hammond, R.; Facciabene, A.; Olvera, N.; Rubin, S.C.; Boyd, J.; Gimotty, P.A.; Coukos, G. Intraepithelial T cells and tumor proliferation: impact on the benefit from surgical cytoreduction in advanced serous ovarian cancer. Cancer 2009, 115, 2891-2902. 
39. Gotlieb, W.H.; Goldberg, I.; Weisz, B.; Davidson, B.; Novikov, I.; Kopolovic, J.; Ben-Baruch, G. Topoisomerase II immunostaining as a prognostic marker for survival in ovarian cancer. Gynecol. Oncol. 2001, 82, 99-104.

40. Marx, D.; Meden, H.; Brune, T.; Kron, M.; Korabiowska, M.; Kuhn, W.; Schauer, A. Mib-1 evaluated proliferative activity in ovarian cancer with respect to prognostic significance. Anticancer Res. 1997, 17, 775-780.

41. Blegen, H.; Einhorn, N.; Sjovall, K.; Roschke, A.; Ghadimi, B. M.; McShane, L.M.; Nilsson, B.; Shah, K.; Ried, T.; Auer, G. Prognostic significance of cell cycle proteins and genomic instability in borderline, early and advanced stage ovarian carcinomas. Int. J. Gynecol. Cancer 2000, 10, 477-487.

42. Khalifeh, I.; Munkarah, A.R.; Schimp, V.; Morris, R.; Lawrence, W.D.; Ali-Fehmi, R. The impact of c-kit and ki-67 expression on patients prognosis in advanced ovarian serous carcinoma. Int. J. Gynecol. Pathol. 2005, 24, 228-234.

43. Elie, C.; Geay, J.F.; Morcos, M.; Le Tourneau, A.; Girre, V.; Broet, P.; Marmey, B.; Chauvenet, L.; Audouin, J.; Pujade-Lauraine, E.; Camilleri-Broet, S. Lack of relationship between EGFR-1 immunohistochemical expression and prognosis in a multicentre clinical trial of 93 patients with advanced primary ovarian epithelial cancer (GINECO group). Br. J. Cancer 2004, 91, 470-475.

44. Camilleri-Broet, S.; Hardy-Bessard, A.C.; Le Tourneau, A.; Paraiso, D.; Levrel, O.; Leduc, B.; Bain, S.; Orfeuvre, H.; Audouin, J.; Pujade-Lauraine, E. HER-2 overexpression is an independent marker of poor prognosis of advanced primary ovarian carcinoma: a multicenter study of the GINECO group. Ann. Oncol. 2004, 15, 104-112.

45. Green, J.A.; Berns, E.M.; Coens, C.; van Luijk, I.; Thompson-Hehir, J.; van Diest, P.; Verheijen, R.H.; van de Vijver, M.; van Dam, P.; Kenter, G. G.; Tjalma, W.; Ewing, P. C.; Teodorovic, I.; Vergote, I.; van der Burg, M. E. Alterations in the p53 pathway and prognosis in advanced ovarian cancer: a multi-factorial analysis of the EORTC Gynaecological Cancer group (study 55865). Eur. J. Cancer 2006, 42, 2539-2548.

46. Ino, K.; Shibata, K.; Kajiyama, H.; Yamamoto, E.; Nagasaka, T.; Nawa, A.; Nomura, S.; Kikkawa, F. Angiotensin II type 1 receptor expression in ovarian cancer and its correlation with tumour angiogenesis and patient survival. Br. J. Cancer 2006, 94, 552-560.

47. Liu, F.S.; Chen, J.T.; Liu, S. C.; Shih, A.; Shih, R.T.; Ho, E.S. Expression and prognostic significance of proliferating cell nuclear antigen and Ki-67 in malignant ovarian germ cell tumors. Zhonghua Yi Xue Za Zhi (Taipei) 1999, 62, 695-702.

48. Schonborn, I.; Minguillon, C.; Mohner, M.; Ebeling, K.[Importance of PCNA proliferating fraction and histomorphologic prognostic factors for survival in breast cancer]. Pathologe 1993, 14, 307-312.

49. Hartmann, L.C.; Sebo, T.J.; Kamel, N.A.; Podratz, K.C.; Cha, S.S.; Wieand, H.S.; Keeney, G.L.; Roche, P.C. Proliferating cell nuclear antigen in epithelial ovarian cancer: relation to results at second-look laparotomy and survival. Gynecol. Oncol. 1992, 47, 191-195.

50. Nijman, H.W.; Kenemans, P.; Poort-Keesom, R.J.; Verstraeten, R.A.; Mensdorff-Pouilly, S.; Verheijen, R. H.; Melief, C.J.; Hilgers, J.; Meijer, C.J. Influence of chemotherapy on the expression of p53, HER-2/neu and proliferation markers in ovarian cancer. Eur. J. Obstet. Gynecol. Reprod. Biol. 1999, 83, 201-206. 
51. Faggad, A.; Darb-Esfahani, S.; Wirtz, R.; Sinn, B.; Sehouli, J.; Konsgen, D.; Lage, H.; Weichert, W.; Noske, A.; Budczies, J.; Muller, B.M.; Buckendahl, A.C.; Roske, A.; Eldin Elwali, N.; Dietel, M.; Denkert, C. Topoisomerase IIalpha mRNA and protein expression in ovarian carcinoma: correlation with clinicopathological factors and prognosis. Mod. Pathol. 2009, 22, 579-588.

52. Kikuchi, Y.; Hirata, J.; Yamamoto, K.; Ishii, K.; Kita, T.; Kudoh, K.; Tode, T.; Nagata, I.; Taniguchi, K.; Kuwano, M. Altered expression of gamma-glutamylcysteine synthetase, metallothionein and topoisomerase I or II during acquisition of drug resistance to cisplatin in human ovarian cancer cells. Jpn. J. Cancer Res. 1997, 88, 213-217.

53. Brustmann, H. Vascular endothelial growth factor expression in serous ovarian carcinoma: relationship with topoisomerase II alpha and prognosis. Gynecol. Oncol. 2004, 95, 16-22.

54. Ferrandina, G.; Petrillo, M.; Carbone, A.; Zannoni, G.; Martinelli, E.; Prisco, M.; Pignata, S.; Breda, E.; Savarese, A.; Scambia, G. Prognostic role of topoisomerase-IIalpha in advanced ovarian cancer patients. Br. J. Cancer 2008, 98, 1910-1915.

55. Mano, M.S.; Awada, A.; Minisini, A.; Atalay, G.; Lago, L.D.; Cardoso, F.; Piccart, M. Remaining controversies in the upfront management of advanced ovarian cancer. Int. J. Gynecol. Cancer 2004, 14, 707-720.

56. Schindlbeck, C.; Hantschmann, P.; Zerzer, M.; Jahns, B.; Rjosk, D.; Janni, W.; Rack, B.; Sommer, H.; Friese, K. Prognostic impact of KI67, p53, human epithelial growth factor receptor 2, topoisomerase IIalpha, epidermal growth factor receptor, and $\mathrm{nm} 23$ expression of ovarian carcinomas and disseminated tumor cells in the bone marrow. Int. J. Gynecol. Cancer 2007, 17, 1047-1055.

57. Rosenberg, E.; Demopoulos, R.I.; Zeleniuch-Jacquotte, A.; Yee, H.; Sorich, J.; Speyer, J.L.; Newcomb, E.W. Expression of cell cycle regulators p57(KIP2), cyclin D1, and cyclin E in epithelial ovarian tumors and survival. Hum. Pathol. 2001, 32, 808-813.

58. Ouellet, V.; Le Page, C.; Madore, J.; Guyot, M.C.; Barres, V.; Lussier, C.; Tonin, P.N.; Provencher, D.M.; Mes-Masson, A.M. An apoptotic molecular network identified by microarray: on the TRAIL to new insights in epithelial ovarian cancer. Cancer 2007, 110, 297-308.

59. Sui, L.; Dong, Y.; Ohno, M.; Sugimoto, K.; Tai, Y.; Hando, T.; Tokuda, M. Implication of malignancy and prognosis of p27(kip1), Cyclin E, and Cdk2 expression in epithelial ovarian tumors. Gynecol. Oncol. 2001, 83, 56-63.

60. Farley, J.; Smith, L.M.; Darcy, K.M.; Sobel, E.; O'Connor, D.; Henderson, B.; Morrison, L.E.; Birrer, M.J. Cyclin E expression is a significant predictor of survival in advanced, suboptimally debulked ovarian epithelial cancers: a Gynecologic Oncology Group study. Cancer Res. 2003, $63,1235-1241$.

61. Rosen, D.G.; Yang, G.; Deavers, M.T.; Malpica, A.; Kavanagh, J.J.; Mills, G. B.; Liu, J. Cyclin E expression is correlated with tumor progression and predicts a poor prognosis in patients with ovarian carcinoma. Cancer 2006, 106, 1925-1932.

62. Bedrosian, I.; Lee, C.; Tucker, S. L.; Palla, S.L.; Lu, K.; Keyomarsi, K. Cyclin E-associated kinase activity predicts response to platinum-based chemotherapy. Clin Cancer Res. 2007, 13, 4800-4806. 
63. Nam, E.J.; Kim, Y.T. Alteration of cell-cycle regulation in epithelial ovarian cancer. Int. J. Gynecol. Cancer 2008, 18, 1169-1182.

64. Bali, A.; O'Brien, P.M.; Edwards, L.S.; Sutherland, R.L.; Hacker, N.F.; Henshall, S.M. Cyclin D1, p53, and p21Waf1/Cip1 expression is predictive of poor clinical outcome in serous epithelial ovarian cancer. Clin. Cancer Res. 2004, 10, 5168-5177.

65. Kusume, T.; Tsuda, H.; Kawabata, M.; Inoue, T.; Umesaki, N.; Suzuki, T.; Yamamoto, K. The p16-cyclin D1/CDK4-pRb pathway and clinical outcome in epithelial ovarian cancer. Clin. Cancer Res. 1999, 5, 4152-4157.

66. Barbieri, F.; Lorenzi, P.; Ragni, N.; Schettini, G.; Bruzzo, C.; Pedulla, F.; Alama, A. Overexpression of cyclin D1 is associated with poor survival in epithelial ovarian cancer. Oncology 2004, 66, 310-315.

67. Barbieri, F.; Cagnoli, M.; Ragni, N.; Foglia, G.; Bruzzo, C.; Pedulla, F.; Alama, A. Increased cyclin D1 expression is associated with features of malignancy and disease recurrence in ovarian tumors. Clin. Cancer Res. 1999, 5, 1837-1842.

68. Levidou, G.; Korkolopoulou, P.; Thymara, I.; Vassilopoulos, I.; Saetta, A.A.; Gakiopoulou, H.; Konstantinidou, A.; Kairi-Vassilatou, E.; Pavlakis, K.; Patsouris, E. Expression and prognostic significance of cyclin D3 in ovarian adenocarcinomas. Int. J. Gynecol. Pathol. 2007, 26, 410-417.

69. Yoon, B.S.; Kim, Y.T.; Kim, S.; Lee, C.S.; Kim, J.W.; Kim, J.H.; Kim, S.W.; Cho, N.H. Prognostic value of nuclear DNA quantification and cyclin A expression in epithelial ovarian carcinoma. Eur. J. Obstet. Gynecol. Reprod. Biol. 2008, 136, 110-115.

70. Davidson, B.; Risberg, B.; Berner, A.; Nesland, J.M.; Trope, C.G.; Kristensen, G.B.; Bryne, M.; Goscinski, M.; van de Putte, G.; Florenes, V.A. Expression of cell cycle proteins in ovarian carcinoma cells in serous effusions-biological and prognostic implications. Gynecol. Oncol. 2001, 83, 249-256.

71. D'Andrilli, G.; Giordano, A.; Bovicelli, A. Epithelial ovarian cancer: the role of cell cycle genes in the different histotypes. Open. Clin. Cancer J. 2008, 2, 7-12.

72. Kallakury, B.V.; Ambros, R.A.; Hayner-Buchan, A.M.; Sheehan, C.E.; Malfetano, J.H.; Ross, J.S. Cell proliferation-associated proteins in endometrial carcinomas, including papillary serous and endometrioid subtypes. Int. J. Gynecol. Pathol. 1998, 17, 320-326.

73. Shigemasa, K.; Shiroyama, Y.; Sawasaki, T.; Fujii, T.; Nagai, N.; Parmley, T. H.; O'Brien, T.J.; Ohama, K. Underexpression of cyclin-dependent kinase inhibitor p27 is associated with poor prognosis in serous ovarian carcinomas. Int. J. Oncol. 2001, 18, 953-958.

74. Masciullo, V.; Ferrandina, G.; Pucci, B.; Fanfani, F.; Lovergine, S.; Palazzo, J.; Zannoni, G.; Mancuso, S.; Scambia, G.; Giordano, A. p27Kip1 expression is associated with clinical outcome in advanced epithelial ovarian cancer: multivariate analysis. Clin. Cancer Res. 2000, 6, 4816-4822.

75. Newcomb, E.W.; Sosnow, M.; Demopoulos, R.I.; Zeleniuch-Jacquotte, A.; Sorich, J.; Speyer, J.L. Expression of the cell cycle inhibitor p27KIP1 is a new prognostic marker associated with survival in epithelial ovarian tumors. Am. J. Pathol. 1999, 154, 119-125. 
76. Schmider-Ross, A.; Pirsig, O.; Gottschalk, E.; Denkert, C.; Lichtenegger, W.; Reles, A. Cyclin-dependent kinase inhibitors CIP1 (p21) and KIP1 (p27) in ovarian cancer. J. Cancer Res. Clin. Oncol. 2006, 132, 163-170.

77. Baekelandt, M.; Holm, R.; Nesland, J. M.; Trope, C.G.; Kristensen, G.B. Expression of apoptosis-related proteins is an independent determinant of patient prognosis in advanced ovarian cancer. J. Clin. Oncol. 2000, 18, 3775-3781.

78. Plisiecka-Halasa, J.; Karpinska, G.; Szymanska, T.; Ziolkowska, I.; Madry, R.; Timorek, A.; Debniak, J.; Ulanska, M.; Jedryka, M.; Chudecka-Glaz, A.; Klimek, M.; Rembiszewska, A.; Kraszewska, E.; Dybowski, B.; Markowska, J.; Emerich, J.; Pluzanska, A.; Goluda, M.; RzepkaGorska, I.; Urbanski, K.; Zielinski, J.; Stelmachow, J.; Chrabowska, M.; Kupryjanczyk, J. P21WAF1, P27KIP1, TP53 and C-MYC analysis in 204 ovarian carcinomas treated with platinum-based regimens. Ann. Oncol. 2003, 14, 1078-1085.

79. Rosen, D.G.; Yang, G.; Cai, K.Q.; Bast, R.C., Jr.; Gershenson, D.M.; Silva, E.G.; Liu, J. Subcellular localization of p27kip1 expression predicts poor prognosis in human ovarian cancer. Clin. Cancer Res. 2005, 11, 632-637.

80. Geisler, J.P.; Geisler, H.E.; Miller, G.A.; Wiemann, M.C.; Zhou, Z.; Crabtree, W. p53 and bcl-2 in epithelial ovarian carcinoma: their value as prognostic indicators at a median follow-up of 60 months. Gynecol. Oncol. 2000, 77, 278-282.

81. Ferrandina, G.; Stoler, A.; Fagotti, A.; Fanfani, F.; Sacco, R.; De Pasqua, A.; Mancuso, S.; Scambia, G. p21WAF1/CIP1 protein expression in primary ovarian cancer. Int. J. Oncol. 2000, 17, 1231-1235.

82. Materna, V.; Surowiak, P.; Markwitz, E.; Spaczynski, M.; Drag-Zalesinska, M.; Zabel, M.; Lage, H. Expression of factors involved in regulation of DNA mismatch repair- and apoptosis pathways in ovarian cancer patients. Oncol. Rep. 2007, 17, 505-516.

83. Schmider, A.; Gee, C.; Friedmann, W.; Lukas, J.J.; Press, M.F.; Lichtenegger, W.; Reles, A. p21 (WAF1/CIP1) protein expression is associated with prolonged survival but not with p53 expression in epithelial ovarian carcinoma. Gynecol. Oncol. 2000, 77, 237-242.

84. Levesque, M.A.; Katsaros, D.; Massobrio, M.; Genta, F.; Yu, H.; Richiardi, G.; Fracchioli, S.; Durando, A.; Arisio, R.; Diamandis, E.P. Evidence for a dose-response effect between p53 (but not p21WAF1/Cip1) protein concentrations, survival, and responsiveness in patients with epithelial ovarian cancer treated with platinum-based chemotherapy. Clin. Cancer Res. 2000, 6, 3260-3270.

85. Schuyer, M.; van der Burg, M.E.; Henzen-Logmans, S.C.; Fieret, J.H.; Klijn, J.G.; Look, M.P.; Foekens, J.A.; Stoter, G.; Berns, E.M. Reduced expression of BAX is associated with poor prognosis in patients with epithelial ovarian cancer: a multifactorial analysis of TP53, p21, BAX and BCL-2. Br. J. Cancer 2001, 85, 1359-1367.

86. Sui, L.; Dong, Y.; Ohno, M.; Watanabe, Y.; Sugimoto, K.; Tokuda, M. Expression of p57kip2 and its clinical relevance in epithelial ovarian tumors. Anticancer Res. 2002, 22, 3191-3196.

87. Kommoss, S.; du Bois, A.; Ridder, R.; Trunk, M.J.; Schmidt, D.; Pfisterer, J.; Kommoss, F. Independent prognostic significance of cell cycle regulator proteins p16(INK4a) and pRb in advanced-stage ovarian carcinoma including optimally debulked patients: a translational research 
subprotocol of a randomised study of the Arbeitsgemeinschaft Gynaekologische Onkologie Ovarian Cancer Study Group. Br. J. Cancer 2007, 96, 306-313.

88. Surowiak, P.; Materna, V.; Maciejczyk, A.; Pudelko, M.; Suchocki, S.; Kedzia, W.; NowakMarkwitz, E.; Dumanska, M.; Spaczynski, M.; Zabel, M.; Dietel, M.; Lage, H. Decreased expression of p16 in ovarian cancers represents an unfavourable prognostic factor. Histol. Histopathol. 2008, 23, 531-538.

89. Sui, L.; Dong, Y.; Ohno, M.; Goto, M.; Inohara, T.; Sugimoto, K.; Tai, Y.; Hando, T.; Tokuda, M. Inverse expression of Cdk4 and p16 in epithelial ovarian tumors. Gynecol. Oncol. 2000, 79, 230-237.

90. Giordano, G.; Azzoni, C.; D'Adda, T.; Rocco, A.; Gnetti, L.; Froio, E.; Merisio, C.; Melpignano, M. Human papilloma virus (HPV) status, p16INK4a, and p53 overexpression in epithelial malignant and borderline ovarian neoplasms. Pathol. Res. Pract. 2008, 204, 163-174.

91. Dong, Y.; Walsh, M.D.; McGuckin, M.A.; Gabrielli, B.G.; Cummings, M.C.; Wright, R.G.; Hurst, T.; Khoo, S. K.; Parsons, P.G. Increased expression of cyclin-dependent kinase inhibitor 2 (CDKN2A) gene product P16INK4A in ovarian cancer is associated with progression and unfavourable prognosis. Int. J. Cancer 1997, 74, 57-63.

92. Duiker, E.W.; Mom, C.H.; de Jong, S.; Willemse, P.H.; Gietema, J.A.; van der Zee, A. G.; de Vries, E.G. The clinical trail of TRAIL. Eur. J. Cancer 2006, 42, 2233-2240.

93. Horak, P.; Pils, D.; Kaider, A.; Pinter, A.; Elandt, K.; Sax, C.; Zielinski, C.C.; Horvat, R.; Zeillinger, R.; Reinthaller, A.; Krainer, M. Perturbation of the tumor necrosis factor--related apoptosis-inducing ligand cascade in ovarian cancer: overexpression of FLIPL and deregulation of the functional receptors DR4 and DR5. Clin. Cancer Res. 2005, 11, 8585-8591.

94. Duiker, E.W.; van der Zee, A.G.; de Graeff, P.; Boersma-van Ek, W.; Hollema, H.; de Bock, G.H.; de Jong, S.; de Vries, E.G. The extrinsic apoptosis pathway and its prognostic impact in ovarian cancer. Gynecol. Oncol. 2009.

95. Bagnoli, M.; Ambrogi, F.; Pilotti, S.; Alberti, P.; Ditto, A.; Barbareschi, M.; Galligioni, E.; Biganzoli, E.; Canevari, S.; Mezzanzanica, D. c-FLIPL expression defines two ovarian cancer patient subsets and is a prognostic factor of adverse outcome. Endocr. Relat. Cancer 2009, 16, 443-453.

96. Munakata, S.; Enomoto, T.; Tsujimoto, M.; Otsuki, Y.; Miwa, H.; Kanno, H.; Aozasa, K. Expressions of Fas ligand and other apoptosis-related genes and their prognostic significance in epithelial ovarian neoplasms. Br. J. Cancer 2000, 82, 1446-1452.

97. Dong, H.P.; Kleinberg, L.; Silins, I.; Florenes, V.A.; Trope, C.G.; Risberg, B.; Nesland, J.M.; Davidson, B. Death receptor expression is associated with poor response to chemotherapy and shorter survival in metastatic ovarian carcinoma. Cancer 2008, 112, 84-93.

98. de la Torre, J.; Gil-Moreno, A.; Garcia, A.; Rojo, F.; Xercavins, J.; Salido, E.; Freire, R. Expression of DNA damage checkpoint protein Hus1 in epithelial ovarian tumors correlates with prognostic markers. Int. J. Gynecol. Pathol. 2008, 27, 24-32.

99. Skirnisdottir, I.; Sorbe, B.; Seidal, T. P53, bcl-2, and bax: their relationship and effect on prognosis in early stage epithelial ovarian carcinoma. Int. J. Gynecol. Cancer 2001, 11, 147-158. 
100. Skirnisdottir, I.; Seidal, T.; Gerdin, E.; Sorbe, B. The prognostic importance of p53, bcl-2, and bax in early stage epithelial ovarian carcinoma treated with adjuvant chemotherapy. Int. J. Gynecol. Cancer 2002, 12, 265-276.

101. Kupryjanczyk, J.; Szymanska, T.; Madry, R.; Timorek, A.; Stelmachow, J.; Karpinska, G.; Rembiszewska, A.; Ziolkowska, I.; Kraszewska, E.; Debniak, J.; Emerich, J.; Ulanska, M.; Pluzanska, A.; Jedryka, M.; Goluda, M.; Chudecka-Glaz, A.; Rzepka-Gorska, I.; Klimek, M.; Urbanski, K.; Breborowicz, J.; Zielinski, J.; Markowska, J. Evaluation of clinical significance of TP53, BCL-2, BAX and MEK1 expression in 229 ovarian carcinomas treated with platinumbased regimen. Br. J. Cancer 2003, 88, 848-854.

102. Ziolkowska-Seta, I.; Madry, R.; Kraszewska, E.; Szymanska, T.; Timorek, A.; Rembiszewska, A.; Kupryjanczyk, J. TP53, BCL-2 and BAX analysis in 199 ovarian cancer patients treated with taxane-platinum regimens. Gynecol. Oncol. 2009, 112, 179-184.

103. Mano, Y.; Kikuchi, Y.; Yamamoto, K.; Kita, T.; Hirata, J.; Tode, T.; Ishii, K.; Nagata, I. Bcl-2 as a predictor of chemosensitivity and prognosis in primary epithelial ovarian cancer. Eur. J. Cancer 1999, 35, 1214-1219.

104. Baekelandt, M.; Kristensen, G.B.; Nesland, J.M.; Trope, C.G.; Holm, R. Clinical significance of apoptosis-related factors p53, Mdm2, and Bcl-2 in advanced ovarian cancer. J. Clin. Oncol. 1999, 17, 2061.

105. Henriksen, R.; Wilander, E.; Oberg, K. Expression and prognostic significance of Bcl-2 in ovarian tumours. Br. J. Cancer 1995, 72, 1324-1329.

106. Malamou-Mitsi, V.; Crikoni, O.; Timotheadou, E.; Aravantinos, G.; Vrettou, E.; Agnantis, N.; Fountzilas, G. Prognostic significance of HER-2, p53 and Bcl-2 in patients with epithelial ovarian cancer. Anticancer Res. 2007, 27, 1157-1165.

107. Skirnisdottir, I.; Sorbe, B.; Karlsson, M.; Seidal, T. Prognostic importance of DNA ploidy and p53 in early stages of epithelial ovarian carcinoma. Int. J. Oncol. 2001, 19, 1295-1302.

108. Tomsova, M.; Melichar, B.; Sedlakova, I.; Steiner, I. Prognostic significance of CD3+ tumorinfiltrating lymphocytes in ovarian carcinoma. Gynecol. Oncol. 2008, 108, 415-420.

109. Herod, J.J.; Eliopoulos, A.G.; Warwick, J.; Niedobitek, G.; Young, L. S.; Kerr, D.J. The prognostic significance of Bcl-2 and p53 expression in ovarian carcinoma. Cancer Res. 1996, 56, 2178-2184.

110. Cohen, C.; Lohmann, C.M.; Cotsonis, G.; Lawson, D.; Santoianni, R. Survivin expression in ovarian carcinoma: correlation with apoptotic markers and prognosis. Mod. Pathol. 2003, 16, 574-583.

111. Lohmann, C.M.; League, A.A.; Clark, W.S.; Lawson, D.; DeRose, P.B.; Cohen, C. Bcl-2: bax and bcl-2: Bcl-x ratios by image cytometric quantitation of immunohistochemical expression in ovarian carcinoma: correlation with prognosis. Cytometry 2000, 42, 61-66.

112. Sagarra, R.A.; Andrade, L.A.; Martinez, E.Z.; Pinto, G.A.; Syrjanen, K.J.; Derchain, S.F. P53 and Bcl-2 as prognostic predictors in epithelial ovarian cancer. Int. Gynecol. Cancer 2002, 12, $720-727$.

113. Elstrand, M.B.; Kleinberg, L.; Kohn, E. C.; Trope, C.G.; Davidson, B. Expression and clinical role of antiapoptotic proteins of the bag, heat shock, and Bcl-2 families in effusions, primary tumors, and solid metastases in ovarian carcinoma. Int. J. Gynecol. Pathol. 2009, 28, 211-221. 
114. Williams, J.; Lucas, P.C.; Griffith, K. A.; Choi, M.; Fogoros, S.; Hu, Y.Y.; Liu, J.R. Expression of Bcl-xL in ovarian carcinoma is associated with chemoresistance and recurrent disease. Gynecol. Oncol. 2005, 96, 287-295.

115. Witty, J.P.; Jensen, R.A.; Johnson, A.L. Expression and localization of Bcl-2 related proteins in human ovarian cancers. Anticancer Res. 1998, 18, 1223-1230.

116. Wehrli, B.M.; Krajewski, S.; Gascoyne, R.D.; Reed, J.C.; Gilks, C.B. Immunohistochemical analysis of bcl-2, bax, mcl-1, and bcl-X expression in ovarian surface epithelial tumors. Int. J. Gynecol. Pathol. 1998, 17, 255-260.

117. Kleinberg, L.; Dong, H.P.; Holth, A.; Risberg, B.; Trope, C.G.; Nesland, J.M.; Florenes, V.A.; Davidson, B. Cleaved caspase-3 and nuclear factor-kappaB p65 are prognostic factors in metastatic serous ovarian carcinoma. Hum. Pathol. 2009, 40, 795-806.

118. Kleinberg, L.; Florenes, V.A.; Silins, I.; Haug, K.; Trope, C.G.; Nesland, J.M.; Davidson, B. Nuclear expression of survivin is associated with improved survival in metastatic ovarian carcinoma. Cancer 2007, 109, 228-238.

119. Sui, L.; Dong, Y.; Ohno, M.; Watanabe, Y.; Sugimoto, K.; Tokuda, M. Survivin expression and its correlation with cell proliferation and prognosis in epithelial ovarian tumors. Int. J. Oncol. 2002, 21, 315-320.

120. Brustmann, H. Poly(adenosine diphosphate-ribose) polymerase expression in serous ovarian carcinoma: correlation with p53, MIB-1, and outcome. Int. J. Gynecol. Patho.l 2007, 26, $147-153$.

121. Steffensen, K.D.; Waldstrom, M.; Jakobsen, A. The relationship of platinum resistance and ERCC1 protein expression in epithelial ovarian cancer. Int. J. Gynecol. Cancer 2009, 19, 820-825.

122. Lin, K.; Ye, D.; Xie, X. Protein expression levels of excision repair cross-complementation group 1 and xeroderma pigmentosum D correlate with response to platinum-based chemotherapy in the patients with advanced epithelial ovarian cancer. Int. J. Gynecol. Cancer 2008, 18, 1007-1012.

123. Weberpals, J.; Garbuio, K.; O'Brien, A.; Clark-Knowles, K.; Doucette, S.; Antoniouk, O.; Goss, G.; Dimitroulakos, J. The DNA repair proteins BRCA1 and ERCC1 as predictive markers in sporadic ovarian cancer. Int. J. Cancer 2009, 124, 806-815.

124. Dabholkar, M.; Bostick-Bruton, F.; Weber, C.; Bohr, V.A.; Egwuagu, C.; Reed, E. ERCC1 and ERCC2 expression in malignant tissues from ovarian cancer patients. J. Natl. Cancer Inst. 1992, $84,1512-1517$.

125. Press, J.Z.; De Luca, A.; Boyd, N.; Young, S.; Troussard, A.; Ridge, Y.; Kaurah, P.; Kalloger, S. E.; Blood, K.A.; Smith, M.; Spellman, P.T.; Wang, Y.; Miller, D.M.; Horsman, D.; Faham, M.; Gilks, C.B.; Gray, J.; Huntsman, D.G. Ovarian carcinomas with genetic and epigenetic BRCA1 loss have distinct molecular abnormalities. BMC Cancer 2008, 8, 17.

126. Hennessy B, T.M. Carey A, Gutin R, Braddus R, Gonzales-Angulo A, Lanchbury J, Lu K, Mills G.B. Somatic BRCA status in ovarina tumors. J. Clin. Oncol. 2009, 27, Abstr. 5528.

127. Kauff, N.D. Is It time to stratify for BRCA mutation status in therapeutic trials in ovarian cancer? J. Clin. Oncol. 2008, 26, 9-10. 
128. Thrall, M.; Gallion, H.H.; Kryscio, R.; Kapali, M.; Armstrong, D.K.; DeLoia, J.A. BRCA1 expression in a large series of sporadic ovarian carcinomas: a Gynecologic Oncology Group study. Int. J. Gynecol. Cancer 2006, 16 (Suppl. 1), 166-171.

129. Sirisabya, N.; Manchana, T.; Termrungreunglert, W.; Triratanachat, S.; Charuruks, N.; Tresukosol, D. Prevalence of BRCA1 expression in epithelial ovarian cancer: immunohistochemical study. J. Med. Assoc. Thai. 2007, 90, 9-14.

130. Martin, L.; Schilder, R. Novel approaches in advancing the treatment of epithelial ovarian cancer: the role of angiogenesis inhibition. J. Clin. Oncol. 2007, 25, 2894-2901.

131. Collinson, F.; Jayson, G. New therapeutic agents in ovarian cancer. Curr. Opin. Obstet Gynecol. 2009, 21, 44-53.

132. Sanchez-Munoz, A.; Perez-Ruiz, E.; Mendiola Fernandez, C.; Alba Conejo, E.; Gonzalez-Martin, A. Current status of anti-angiogenic agents in the treatment of ovarian carcinoma. Clin. Transl. Oncol. 2009, 11, 589-595.

133. Weidner, N.; Semple, J.P.; Welch, W. R.; Folkman, J. Tumor angiogenesis and metastasis-correlation in invasive breast carcinoma. N. Engl. J. Med. 1991, 324, 1-8.

134. Orre, M.; Lotfi-Miri, M.; Mamers, P.; Rogers, P.A. Increased microvessel density in mucinous compared with malignant serous and benign tumours of the ovary. Br. J. Cancer 1998, 77, 2204-2209.

135. Stone, P.J.; Goodheart, M.J.; Rose, S.L.; Smith, B.J.; DeYoung, B.R.; Buller, R.E. The influence of microvessel density on ovarian carcinogenesis. Gynecol. Oncol. 2003, 90, 566-571.

136. Gasparini, G.; Bonoldi, E.; Viale, G.; Verderio, P.; Boracchi, P.; Panizzoni, G.A.; Radaelli, U.; Di Bacco, A.; Guglielmi, R. B.; Bevilacqua, P. Prognostic and predictive value of tumour angiogenesis in ovarian carcinomas. Int. J. Cancer 1996, 69, 205-211.

137. Alvarez, A.A.; Krigman, H.R.; Whitaker, R.S.; Dodge, R.K.; Rodriguez, G.C. The prognostic significance of angiogenesis in epithelial ovarian carcinoma. Clin. Cancer Res. 1999, 5, 587-591.

138. Schoell, W.M.; Pieber, D.; Reich, O.; Lahousen, M.; Janicek, M.; Guecer, F.; Winter, R. Tumor angiogenesis as a prognostic factor in ovarian carcinoma: quantification of endothelial immunoreactivity by image analysis. Cancer 1997, 80, 2257-2262.

139. Taskiran, C.; Erdem, O.; Onan, A.; Arisoy, O.; Acar, A.; Vural, C.; Erdem, M.; Ataoglu, O.; Guner, H. The prognostic value of endoglin (CD105) expression in ovarian carcinoma. Int. J. Gynecol. Cancer 2006, 16, 1789-1793.

140. Gadducci, A.; Viacava, P.; Cosio, S.; Fanelli, G.; Fanucchi, A.; Cecchetti, D.; Cristofani, R.; Genazzani, A.R. Intratumoral microvessel density, response to chemotherapy and clinical outcome of patients with advanced ovarian carcinoma. Anticancer Res. 2003, 23, 549-556.

141. Chan, J.K.; Zhang, M.; Kaleb, V.; Loizzi, V.; Benjamin, J.; Vasilev, S.; Osann, K.; Disaia, P.J. Prognostic factors responsible for survival in sex cord stromal tumors of the ovary--a multivariate analysis. Gynecol. Oncol. 2005, 96, 204-209.

142. Goodheart, M.J.; Ritchie, J.M.; Rose, S.L.; Fruehauf, J.P.; De Young, B.R.; Buller, R.E. The relationship of molecular markers of p53 function and angiogenesis to prognosis of stage I epithelial ovarian cancer. Clin. Cancer Res. 2005, 11, 3733-3742.

143. Ogawa, S.; Kaku, T.; Kobayashi, H.; Hirakawa, T.; Ohishi, Y.; Kinukawa, N.; Nakano, H. Prognostic significance of microvessel density, vascular cuffing and vascular endothelial growth 
factor expression in ovarian carcinoma: a special review for clear cell adenocarcinoma. Cancer Lett. 2002, 176, 111-118.

144. Palmer, J.E.; Sant Cassia, L.J.; Irwin, C.J.; Morris, A.G.; Rollason, T.P. Prognostic value of measurements of angiogenesis in serous carcinoma of the ovary. Int. J. Gynecol. Pathol. 2007, 26, 395-403.

145. Suhonen, K.A.; Anttila, M.A.; Sillanpaa, S.M.; Hamalainen, K.M.; Saarikoski, S.V.; Juhola, M.; Kosma, V.M. Quantification of angiogenesis by the Chalkley method and its prognostic significance in epithelial ovarian cancer. Eur. J. Cancer 2007, 43, 1300-1307.

146. Hollingsworth, H.C.; Kohn, E.C.; Steinberg, S.M.; Rothenberg, M.L.; Merino, M.J. Tumor angiogenesis in advanced stage ovarian carcinoma. Am. J. Pathol. 1995, 147, 33-41.

147. Heimburg, S.; Oehler, M.K.; Papadopoulos, T.; Caffier, H.; Kristen, P.; Dietl, J. Prognostic relevance of the endothelial marker CD 34 in ovarian cancer. Anticancer Res. 1999, 19, 2527-2529.

148. Obermair, A.; Wasicky, R.; Kaider, A.; Preyer, O.; Losch, A.; Leodolter, S.; Kolbl, H. Prognostic significance of tumor angiogenesis in epithelial ovarian cancer. Cancer Lett. 1999, 138, 175-182.

149. Birner, P.; Schindl, M.; Obermair, A.; Breitenecker, G.; Oberhuber, G. Expression of hypoxiainducible factor 1alpha in epithelial ovarian tumors: its impact on prognosis and on response to chemotherapy. Clin. Cancer Res. 2001, 7, 1661-1668.

150. Ali-Fehmi, R.; Morris, R.T.; Bandyopadhyay, S.; Che, M.; Schimp, V.; Malone, J.M., Jr.; Munkarah, A.R. Expression of cyclooxygenase-2 in advanced stage ovarian serous carcinoma: correlation with tumor cell proliferation, apoptosis, angiogenesis, and survival. Am. J. Obstet. Gynecol. 2005, 192, 819-825.

151. Raspollini, M.R.; Amunni, G.; Villanucci, A.; Boddi, V.; Baroni, G.; Taddei, A.; Taddei, G.L. COX-2 status in relation to tumor microvessel density and VEGF expression: analysis in ovarian carcinoma patients with low versus high survival rates. Oncol. Rep. 2004, 11, 309-313.

152. Engels, K.; du Bois, A.; Harter, P.; Fisseler-Eckhoff, A.; Kommoss, F.; Stauber, R.; Kaufmann, M.; Nekljudova, V.; Loibl, S. VEGF-A and i-NOS expression are prognostic factors in serous epithelial ovarian carcinomas after complete surgical resection. J. Clin. Pathol. 2009, 62, 448-454.

153. Raspollini, M.R.; Castiglione, F.; Garbini, F.; Villanucci, A.; Amunni, G.; Baroni, G.; Boddi, V.; Taddei, G.L. Correlation of epidermal growth factor receptor expression with tumor microdensity vessels and with vascular endothelial growth factor expression in ovarian carcinoma. Int. J. Surg. Pathol. 2005, 13, 135-142.

154. Shen, G.H.; Ghazizadeh, M.; Kawanami, O.; Shimizu, H.; Jin, E.; Araki, T.; Sugisaki, Y. Prognostic significance of vascular endothelial growth factor expression in human ovarian carcinoma. Br. J. Cancer 2000, 83, 196-203.

155. Shimogai, R.; Kigawa, J.; Itamochi, H.; Iba, T.; Kanamori, Y.; Oishi, T.; Shimada, M.; Sato, S.; Kawaguchi, W.; Terakawa, N. Expression of hypoxia-inducible factor 1alpha gene affects the outcome in patients with ovarian cancer. Int. J. Gynecol. Cancer 2008, 18, 499-505.

156. Yamamoto, S.; Konishi, I.; Mandai, M.; Kuroda, H.; Komatsu, T.; Nanbu, K.; Sakahara, H.; Mori, T. Expression of vascular endothelial growth factor (VEGF) in epithelial ovarian 
neoplasms: correlation with clinicopathology and patient survival, and analysis of serum VEGF levels. Br. J. Cancer 1997, 76, 1221-1227.

157. Bamias, A.; Koutsoukou, V.; Terpos, E.; Tsiatas, M. L.; Liakos, C.; Tsitsilonis, O.; Rodolakis, A.; Voulgaris, Z.; Vlahos, G.; Papageorgiou, T.; Papatheodoridis, G.; Archimandritis, A.; Antsaklis, A.; Dimopoulos, M. A. Correlation of NK T-like CD3+CD56+ cells and CD4+CD25+(hi) regulatory $\mathrm{T}$ cells with VEGF and TNFalpha in ascites from advanced ovarian cancer: Association with platinum resistance and prognosis in patients receiving first-line, platinum-based chemotherapy. Gynecol. Oncol. 2008, 108, 421-427.

158. Garzetti, G.G.; Ciavattini, A.; Lucarini, G.; Pugnaloni, A.; De Nictolis, M.; Amati, S.; Romanini, C.; Biagini, G. Expression of vascular endothelial growth factor related to 72-kilodalton metalloproteinase immunostaining in patients with serous ovarian tumors. Cancer 1999, 85, 2219-2225.

159. Secord, A.A.; Darcy, K.M.; Hutson, A.; Lee, P.S.; Havrilesky, L.J.; Grace, L.A.; Berchuck, A. Co-expression of angiogenic markers and associations with prognosis in advanced epithelial ovarian cancer: a Gynecologic Oncology Group study. Gynecol. Oncol. 2007, 106, 221-232.

160. Gadducci, A.; Viacava, P.; Cosio, S.; Cecchetti, D.; Fanelli, G.; Fanucchi, A.; Teti, G.; Genazzani, A.R. Vascular endothelial growth factor (VEGF) expression in primary tumors and peritoneal metastases from patients with advanced ovarian carcinoma. Anticancer Res. 2003, 23, 3001-3008.

161. Duncan, T.J.; Al-Attar, A.; Rolland, P.; Scott, I.V.; Deen, S.; Liu, D.T.; Spendlove, I.; Durrant, L.G. Vascular endothelial growth factor expression in ovarian cancer: a model for targeted use of novel therapies? Clin. Cancer Res. 2008, 14, 3030-3035.

162. O'Toole, S.A.; Sheppard, B.L.; Laios, A.; O'Leary, J.J.; McGuinness, E. P.; D'Arcy, T.; Bonnar, J. Potential predictors of chemotherapy response in ovarian cancer--how do we define chemosensitivity? Gynecol. Oncol. 2007, 104, 345-351.

163. Hefler, L.A.; Zeillinger, R.; Grimm, C.; Sood, A.K.; Cheng, W.F.; Gadducci, A.; Tempfer, C.B.; Reinthaller, A. Preoperative serum vascular endothelial growth factor as a prognostic parameter in ovarian cancer. Gynecol. Oncol. 2006, 103, 512-517.

164. Daponte, A.; Kostopoulou, E.; Minas, M.; Koukoulis, G.; Messinis, I. E. Prognostic significance of fascin expression in advanced poorly differentiated serous ovarian cancer. Anticancer Res. 2008, 28, 1905-1910.

165. Lee, S.; Garner, E.I.; Welch, W.R.; Berkowitz, R.S.; Mok, S.C. Over-expression of hypoxiainducible factor 1 alpha in ovarian clear cell carcinoma. Gynecol. Oncol. 2007, 106, 311-317.

166. Osada, R.; Horiuchi, A.; Kikuchi, N.; Yoshida, J.; Hayashi, A.; Ota, M.; Katsuyama, Y.; Melillo, G.; Konishi, I. Expression of hypoxia-inducible factor 1alpha, hypoxia-inducible factor 2alpha, and von Hippel-Lindau protein in epithelial ovarian neoplasms and allelic loss of von HippelLindau gene: nuclear expression of hypoxia-inducible factor 1alpha is an independent prognostic factor in ovarian carcinoma. Hum. Pathol. 2007, 38, 1310-1320.

167. Nakai, H.; Watanabe, Y.; Ueda, H.; Hoshiai, H. Hypoxia inducible factor 1-alpha expression as a factor predictive of efficacy of taxane/platinum chemotherapy in advanced primary epithelial ovarian cancer. Cancer Lett. 2007, 251, 164-167. 
168. Erkinheimo, T.L.; Lassus, H.; Finne, P.; van Rees, B.P.; Leminen, A.; Ylikorkala, O.; Haglund, C.; Butzow, R.; Ristimaki, A. Elevated cyclooxygenase-2 expression is associated with altered expression of p53 and SMAD4, amplification of HER-2/neu, and poor outcome in serous ovarian carcinoma. Clin. Cancer Res. 2004, 10, 538-545.

169. Seo, S.S.; Song, Y.S.; Kang, D.H.; Park, I.A.; Bang, Y.J.; Kang, S.B.; Lee, H.P. Expression of cyclooxygenase-2 in association with clinicopathological prognostic factors and molecular markers in epithelial ovarian cancer. Gynecol. Oncol. 2004, 92, 927-935.

170. Ali-Fehmi, R.; Che, M.; Khalifeh, I.; Malone, J.M.; Morris, R.; Lawrence, W.D.; Munkarah, A.R. The effect of cyclooxygenase- 2 expression on tumor vascularity in advanced stage ovarian serous carcinoma. Cancer 2003, 98, 1423-1429.

171. Khalifeh, I.; Munkarah, A. R.; Lonardo, F.; Malone, J. M.; Morris, R.; Lawrence, W.D.; AliFehmi, R. Expression of Cox-2, CD34, Bcl-2, and p53 and survival in patients with primary peritoneal serous carcinoma and primary ovarian serous carcinoma. Int. J. Gynecol. Pathol. 2004, 23, 162-169.

172. Raspollini, M.R.; Susini, T.; Taddei, G.L. Expression of metalloproteinases 2 and 9 and cyclooxygenase 2 in endometrial carcinoma. Int. J. Gynaecol. Obstet. 2006, 93, 64-66.

173. Athanassiadou, P.; Grapsa, D.; Athanassiades, P.; Gonidi, M.; Athanassiadou, A.M.; Tsipis, A.; Patsouris, E. The prognostic significance of COX-2 and survivin expression in ovarian cancer. Pathol. Res. Pract. 2008, 204, 241-249.

174. Raspollini, M.R.; Amunni, G.; Villanucci, A.; Boddi, V.; Baroni, G.; Taddei, A.; Taddei, G.L. Expression of inducible nitric oxide synthase and cyclooxygenase-2 in ovarian cancer: correlation with clinical outcome. Gynecol. Oncol. 2004, 92, 806-812.

175. Surowiak, P.; Materna, V.; Denkert, C.; Kaplenko, I.; Spaczynski, M.; Dietel, M.; Zabel, M.; Lage, H. Significance of cyclooxygenase 2 and MDR1/P-glycoprotein coexpression in ovarian cancers. Cancer Lett. 2006, 235, 272-280.

176. Denkert, C.; Kobel, M.; Pest, S.; Koch, I.; Berger, S.; Schwabe, M.; Siegert, A.; Reles, A.; Klosterhalfen, B.; Hauptmann, S. Expression of cyclooxygenase 2 is an independent prognostic factor in human ovarian carcinoma. Am. J. Pathol. 2002, 160, 893-903.

177. Ferrandina, G.; Lauriola, L.; Zannoni, G.F.; Fagotti, A.; Fanfani, F.; Legge, F.; Maggiano, N.; Gessi, M.; Mancuso, S.; Ranelletti, F. O.; Scambia, G. Increased cyclooxygenase-2 (COX-2) expression is associated with chemotherapy resistance and outcome in ovarian cancer patients. Ann. Oncol. 2002, 13, 1205-1211.

178. Steffensen, K.D.; Waldstrom, M.; Jeppesen, U.; Jakobsen, E.; Brandslund, I.; Jakobsen, A. The prognostic importance of cyclooxygenase 2 and HER2 expression in epithelial ovarian cancer. Int. J. Gynecol. Cancer 2007, 17, 798-807.

179. Alvarez, A.A.; Axelrod, J.R.; Whitaker, R.S.; Isner, P.D.; Bentley, R.C.; Dodge, R.K.; Rodriguez, G.C. Thrombospondin-1 expression in epithelial ovarian carcinoma: association with p53 status, tumor angiogenesis, and survival in platinum-treated patients. Gynecol. Oncol. 2001, 82, 273-278.

180. Karavasilis, V.; Malamou-Mitsi, V.; Briasoulis, E.; Tsanou, E.; Kitsou, E.; Pavlidis, N. Clinicopathologic study of vascular endothelial growth factor, thrombospondin-1, and 
microvessel density assessed by CD34 in patients with stage III ovarian carcinoma. Int. J. Gynecol. Cancer 2006, 16 (Suppl. 1), 241-246.

181. Egeblad, M.; Werb, Z. New functions for the matrix metalloproteinases in cancer progression. Nat. Rev. Cancer 2002, 2, 161-174.

182. Raspollini, M.R.; Taddei, G.L. Tumor markers in ovarian carcinoma. Int. J. Gynaecol. Obstet. 2007, 97, 175-181.

183. Davidson, B.; Goldberg, I.; Kopolovic, J.; Gotlieb, W.H.; Givant-Horwitz, V.; Nesland, J.M.; Berner, A.; Ben-Baruch, G.; Bryne, M.; Reich, R. Expression of angiogenesis-related genes in ovarian carcinoma--a clinicopathologic study. Clin. Exp. Metastasis 2000, 18, 501-507.

184. Sillanpaa, S.; Anttila, M.; Voutilainen, K.; Ropponen, K.; Turpeenniemi-Hujanen, T.; Puistola, U.; Tammi, R.; Tammi, M.; Sironen, R.; Saarikoski, S.; Kosma, V.M. Prognostic significance of matrix metalloproteinase-9 (MMP-9) in epithelial ovarian cancer. Gynecol. Oncol. 2007, 104, 296-303.

185. Sillanpaa, S.M.; Anttila, M.A.; Voutilainen, K.A.; Ropponen, K.M.; Sironen, R.K.; Saarikoski, S.V.; Kosma, V.M. Prognostic significance of matrix metalloproteinase-7 in epithelial ovarian cancer and its relation to beta-catenin expression. Int. J. Cancer 2006, 119, 1792-1799.

186. Zhang, L.; Conejo-Garcia, J. R.; Katsaros, D.; Gimotty, P. A.; Massobrio, M.; Regnani, G.; Makrigiannakis, A.; Gray, H.; Schlienger, K.; Liebman, M.N.; Rubin, S. C.; Coukos, G. Intratumoral T cells, recurrence, and survival in epithelial ovarian cancer. N. Engl. J. Med. 2003, 348, 203-213.

187. Curiel, T.J.; Coukos, G.; Zou, L.; Alvarez, X.; Cheng, P.; Mottram, P.; Evdemon-Hogan, M.; Conejo-Garcia, J. R.; Zhang, L.; Burow, M.; Zhu, Y.; Wei, S.; Kryczek, I.; Daniel, B.; Gordon, A.; Myers, L.; Lackner, A.; Disis, M. L.; Knutson, K. L.; Chen, L.; Zou, W. Specific recruitment of regulatory $\mathrm{T}$ cells in ovarian carcinoma fosters immune privilege and predicts reduced survival. Nat. Med. 2004, 10, 942-949.

188. Hamanishi, J.; Mandai, M.; Iwasaki, M.; Okazaki, T.; Tanaka, Y.; Yamaguchi, K.; Higuchi, T.; Yagi, H.; Takakura, K.; Minato, N.; Honjo, T.; Fujii, S. Programmed cell death 1 ligand 1 and tumor-infiltrating CD8+ T lymphocytes are prognostic factors of human ovarian cancer. Proc. Natl. Acad. Sci. USA 2007, 104, 3360-3365.

189. Clarke, B.; Tinker, A. V.; Lee, C. H.; Subramanian, S.; van de Rijn, M.; Turbin, D.; Kalloger, S.; Han, G.; Ceballos, K.; Cadungog, M.G.; Huntsman, D.G.; Coukos, G.; Gilks, C.B. Intraepithelial $\mathrm{T}$ cells and prognosis in ovarian carcinoma: novel associations with stage, tumor type, and BRCA1 loss. Mod. Pathol. 2009, 22, 393-402.

190. Leffers, N.; Gooden, M.J.; de Jong, R.A.; Hoogeboom, B.N.; ten Hoor, K.A.; Hollema, H.; Boezen, H.M.; van der Zee, A.G.; Daemen, T.; Nijman, H.W. Prognostic significance of tumorinfiltrating T-lymphocytes in primary and metastatic lesions of advanced stage ovarian cancer. Cancer Immunol. Immunother. 2009, 58, 449-459.

191. Kryczek, I.; Banerjee, M.; Cheng, P.; Vatan, L.; Szeliga, W.; Wei, S.; Huang, E.; Finlayson, E.; Simeone, D.; Welling, T.H.; Chang, A.; Coukos, G.; Liu, R.; Zou, W. Phenotype, distribution, generation, functional and clinical relevance of Th17 cells in the human tumor environments. Blood 2009, 1144, 1141-1149. 
192. Stumpf, M.; Hasenburg, A.; Riener, M.O.; Jutting, U.; Wang, C.; Shen, Y.; Orlowska-Volk, M.; Fisch, P.; Wang, Z.; Gitsch, G.; Werner, M.; Lassmann, S. Intraepithelial CD8-positive T lymphocytes predict survival for patients with serous stage III ovarian carcinomas: relevance of clonal selection of T lymphocytes. Br. J. Cancer 2009, 101, 1513-1521.

193. Nelson, B.H. The impact of T-cell immunity on ovarian cancer outcomes. Immunol. Rev. 2008, 222, 101-116.

194. Al-Attar, A.; Shehata, M.; Durrant, L.; Moseley, P.; Deen, S.; Chan, S. T Cell Density and Location Can Influence the Prognosis of Ovarian Cancer. Pathol. Oncol. Res. 2009, doi: 10.1007/s 12253-009-9230-5.

195. Wolf, D.; Wolf, A.M.; Rumpold, H.; Fiegl, H.; Zeimet, A.G.; Muller-Holzner, E.; Deibl, M.; Gastl, G.; Gunsilius, E.; Marth, C. The expression of the regulatory T cell-specific forkhead box transcription factor FoxP3 is associated with poor prognosis in ovarian cancer. Clin. Cancer Res. 2005, 11, 8326-8331.

196. Sato, E.; Olson, S.H.; Ahn, J.; Bundy, B.; Nishikawa, H.; Qian, F.; Jungbluth, A.A.; Frosina, D.; Gnjatic, S.; Ambrosone, C.; Kepner, J.; Odunsi, T.; Ritter, G.; Lele, S.; Chen, Y.T.; Ohtani, H.; Old, L.J.; Odunsi, K. Intraepithelial CD8+ tumor-infiltrating lymphocytes and a high $\mathrm{CD} 8+/$ regulatory $\mathrm{T}$ cell ratio are associated with favorable prognosis in ovarian cancer. Proc. Natl. Acad. Sci. USA 2005, 102, 18538-18543.

197. Kryczek, I.; Liu, R.; Wang, G.; Wu, K.; Shu, X.; Szeliga, W.; Vatan, L.; Finlayson, E.; Huang, E.; Simeone, D.; Redman, B.; Welling, T.H.; Chang, A.; Zou, W. FOXP3 defines regulatory T cells in human tumor and autoimmune disease. Cancer Res. 2009, 69, 3995-4000.

198. Zeimet, A.G.; Reimer, D.; Wolf, D.; Fiegl, H.; Concin, N.; Wiedemair, A.; Wolf, A.M.; Rumpold, H.; Muller-Holzner, E.; Marth, C. Intratumoral interferon regulatory factor (IRF)-1 but not IRF-2 is of relevance in predicting patient outcome in ovarian cancer. Int. J. Cancer 2009, 124, 2353-2360.

199. Polcher, M.; Braun, M.; Friedrichs, N.; Rudlowski, C.; Bercht, E.; Fimmers, R.; Sauerwald, A.; Keyver-Paik, M.D.; Kubler, K.; Buttner, R.; Kuhn, W.C.; Hernando, J.J. Foxp3(+) cell infiltration and granzyme $\mathrm{B}(+) /$ Foxp3 $(+)$ cell ratio are associated with outcome in neoadjuvant chemotherapy-treated ovarian carcinoma. Cancer Immunol. Immunother. 2010, 59, 909-919.

200. Milne, K.; Kobel, M.; Kalloger, S.E.; Barnes, R.O.; Gao, D.; Gilks, C.B.; Watson, P.H.; Nelson, B.H. Systematic analysis of immune infiltrates in high-grade serous ovarian cancer reveals CD20, FoxP3 and TIA-1 as positive prognostic factors. PLoS One 2009, 4, e6412.

201. Fei, M.; Zhao, Y.; Wang, Y.; Lu, M.; Cheng, C.; Huang, X.; Zhang, D.; Lu, J.; He, S.; Shen, A. Low expression of Foxo3a is associated with poor prognosis in ovarian cancer patients. Cancer Invest. 2009, 27, 52-59.

202. Curiel, T.J.; Wei, S.; Dong, H.; Alvarez, X.; Cheng, P.; Mottram, P.; Krzysiek, R.; Knutson, K.L.; Daniel, B.; Zimmermann, M.C.; David, O.; Burow, M.; Gordon, A.; Dhurandhar, N.; Myers, L.; Berggren, R.; Hemminki, A.; Alvarez, R.D.; Emilie, D.; Curiel, D.T.; Chen, L.; Zou, W. Blockade of B7-H1 improves myeloid dendritic cell-mediated antitumor immunity. Nat. Med. 2003, 9, 562-567.

203. Bamias, A.; Tsiatas, M.L.; Kafantari, E.; Liakou, C.; Rodolakis, A.; Voulgaris, Z.; Vlahos, G.; Papageorgiou, T.; Tsitsilonis, O.; Bamia, C.; Papatheodoridis, G.; Politi, E.; Archimandritis, A.; 
Antsaklis, A.; Dimopoulos, M.A. Significant differences of lymphocytes isolated from ascites of patients with ovarian cancer compared to blood and tumor lymphocytes. Association of CD3+CD56+ cells with platinum resistance. Gynecol. Oncol. 2007, 106, 75-81.

204. Kryczek, I.; Wei, S.; Zhu, G.; Myers, L.; Mottram, P.; Cheng, P.; Chen, L.; Coukos, G.; Zou, W. Relationship between B7-H4, regulatory $\mathrm{T}$ cells, and patient outcome in human ovarian carcinoma. Cancer Res. 2007, 67, 8900-8905.

205. Leng, J.; Lang, J.; Shen, K.; Guo, L. Overexpression of p53, EGFR, c-erbB2 and c-erbB3 in endometrioid carcinoma of the ovary. Chin. Med. Sci. J. 1997, 12, 67-70.

206. Tanner, B.; Hasenclever, D.; Stern, K.; Schormann, W.; Bezler, M.; Hermes, M.; Brulport, M.; Bauer, A.; Schiffer, I. B.; Gebhard, S.; Schmidt, M.; Steiner, E.; Sehouli, J.; Edelmann, J.; Lauter, J.; Lessig, R.; Krishnamurthi, K.; Ullrich, A.; Hengstler, J.G. ErbB-3 predicts survival in ovarian cancer. J. Clin. Oncol. 2006, 24, 4317-4323.

207. Skirnisdottir, I.; Sorbe, B.; Seidal, T. The growth factor receptors HER-2/neu and EGFR, their relationship, and their effects on the prognosis in early stage (FIGO I-II) epithelial ovarian carcinoma. Int. J. Gynecol. Cancer 2001, 11, 119-129.

208. Noren, N.K.; Lu, M.; Freeman, A.L.; Koolpe, M.; Pasquale, E. B. Interplay between EphB4 on tumor cells and vascular ephrin-B2 regulates tumor growth. Proc. Natl. Acad. Sci. USA 2004, $101,5583-5588$.

209. Kumar, S.R.; Masood, R.; Spannuth, W.A.; Singh, J.; Scehnet, J.; Kleiber, G.; Jennings, N.; Deavers, M.; Krasnoperov, V.; Dubeau, L.; Weaver, F.A.; Sood, A.K.; Gill, P.S. The receptor tyrosine kinase EphB4 is overexpressed in ovarian cancer, provides survival signals and predicts poor outcome. Br. J. Cancer 2007, 96, 1083-1091.

210. Wu, Q.; Suo, Z.; Kristensen, G.B.; Baekelandt, M.; Nesland, J.M. The prognostic impact of EphB2/B4 expression on patients with advanced ovarian carcinoma. Gynecol. Oncol. 2006, 102, $15-21$.

211. Alam, S.M.; Fujimoto, J.; Jahan, I.; Sato, E.; Tamaya, T. Coexpression of EphB4 and ephrinB2 in tumour advancement of ovarian cancers. Br. J. Cancer 2008, 98, 845-851.

212. Ouellet, V.; Guyot, M.C.; Le Page, C.; Filali-Mouhim, A.; Lussier, C.; Tonin, P.N.; Provencher, D.M.; Mes-Masson, A.M. Tissue array analysis of expression microarray candidates identifies markers associated with tumor grade and outcome in serous epithelial ovarian cancer. Int. J. Cancer 2006, 119, 599-607.

213. Sawada, K.; Radjabi, A.R.; Shinomiya, N.; Kistner, E.; Kenny, H.; Becker, A.R.; Turkyilmaz, M.A.; Salgia, R.; Yamada, S.D.; Vande Woude, G.F.; Tretiakova, M.S.; Lengyel, E. c-Met overexpression is a prognostic factor in ovarian cancer and an effective target for inhibition of peritoneal dissemination and invasion. Cancer Res. 2007, 67, 1670-1679.

214. Guo, R.X.; Qiao, Y.H.; Zhou, Y.; Li, L.X.; Shi, H.R.; Chen, K.S. Increased staining for phosphorylated AKT and nuclear factor-kappaB p65 and their relationship with prognosis in epithelial ovarian cancer. Pathol. Int. 2008, 58, 749-756.

215. Eckstein, N.; Servan, K.; Hildebrandt, B.; Politz, A.; von Jonquieres, G.; Wolf-Kummeth, S.; Napierski, I.; Hamacher, A.; Kassack, M.U.; Budczies, J.; Beier, M.; Dietel, M.; Royer-Pokora, B.; Denkert, C.; Royer, H.D. Hyperactivation of the insulin-like growth factor receptor I 
signaling pathway is an essential event for cisplatin resistance of ovarian cancer cells. Cancer Res. 2009, 69, 2996-3003.

216. Castellvi, J.; Garcia, A.; Rojo, F.; Ruiz-Marcellan, C.; Gil, A.; Baselga, J.; Ramon y Cajal, S. Phosphorylated 4E binding protein 1: a hallmark of cell signaling that correlates with survival in ovarian cancer. Cancer 2006, 107, 1801-1811.

217. Ohta, T.; Isobe, M.; Takahashi, T.; Saitoh-Sekiguchi, M.; Motoyama, T.; Kurachi, H. The Akt and ERK activation by platinum-based chemotherapy in ovarian cancer is associated with favorable patient outcome. Anticancer Res. 2009, 29, 4639-4647.

218. de Graeff, P.; Crijns, A.P.; Ten Hoor, K.A.; Klip, H.G.; Hollema, H.; Oien, K.; Bartlett, J.M.; Wisman, G.B.; de Bock, G.H.; de Vries, E.G.; de Jong, S.; van der Zee, A.G. The ErbB signalling pathway: protein expression and prognostic value in epithelial ovarian cancer. Br. J. Cancer 2008, 99, 341-349.

219. Wang, Y.; Kristensen, G.B.; Helland, A.; Nesland, J.M.; Borresen-Dale, A.L.; Holm, R. Protein expression and prognostic value of genes in the erb-b signaling pathway in advanced ovarian carcinomas. Am. J. Clin. Pathol. 2005, 124, 392-401.

220. Faleiro-Rodrigues, C.; Macedo-Pinto, I.; Pereira, D.; Lopes, C. S. Prognostic value of E-cadherin immunoexpression in patients with primary ovarian carcinomas. Ann. Oncol. 2004, 15, $1535-1542$.

221. Cho, E.Y.; Choi, Y.; Chae, S. W.; Sohn, J.H.; Ahn, G.H. Immunohistochemical study of the expression of adhesion molecules in ovarian serous neoplasms. Pathol. Int. 2006, 56, 62-70.

222. Shim, H.S.; Yoon, B.S.; Cho, N.H. Prognostic significance of paired epithelial cell adhesion molecule and E-cadherin in ovarian serous carcinoma. Hum. Pathol. 2009, 40, 693-698.

223. Voutilainen, K.A.; Anttila, M.A.; Sillanpaa, S.M.; Ropponen, K.M.; Saarikoski, S.V.; Juhola, M.T.; Kosma, V.M. Prognostic significance of E-cadherin-catenin complex in epithelial ovarian cancer. J. Clin. Pathol. 2006, 59, 460-467.

224. Kildal, W.; Risberg, B.; Abeler, V.M.; Kristensen, G.B.; Sudbo, J.; Nesland, J.M.; Danielsen, H.E. beta-catenin expression, DNA ploidy and clinicopathological features in ovarian cancer: a study in 253 patients. Eur. J. Cancer 2005, 41, 1127-1134.

225. Bast, R.C., Jr.; Lilja, H.; Urban, N.; Rimm, D.L.; Fritsche, H.; Gray, J.; Veltri, R.; Klee, G.; Allen, A.; Kim, N.; Gutman, S.; Rubin, M.A.; Hruszkewycz, A. Translational crossroads for biomarkers. Clin. Cancer Res. 2005, 11, 6103-6108.

226. McShane, L.M.; Altman, D.G.; Sauerbrei, W.; Taube, S.E.; Gion, M.; Clark, G.M. REporting recommendations for tumour MARKer prognostic studies (REMARK). Eur. J. Cancer 2005, 41, 1690-1696.

227. Ramus, S.J.; Vierkant, R.A.; Johnatty, S.E.; Pike, M.C.; Van Den Berg, D.J.; Wu, A.H.; Pearce, C.L.; Menon, U.; Gentry-Maharaj, A.; Gayther, S.A.; Dicioccio, R.A.; McGuire, V.; Whittemore, A. S.; Song, H.; Easton, D.F.; Pharoah, P.D.; Garcia-Closas, M.; Chanock, S.; Lissowska, J.; Brinton, L.; Terry, K.L.; Cramer, D.W.; Tworoger, S.S.; Hankinson, S.E.; Berchuck, A.; Moorman, P.G.; Schildkraut, J.M.; Cunningham, J.M.; Liebow, M.; Kjaer, S.K.; Hogdall, E.; Hogdall, C.; Blaakaer, J.; Ness, R.B.; Moysich, K. B.; Edwards, R.P.; Carney, M.E.; Lurie, G.; Goodman, M.T.; Wang-Gohrke, S.; Kropp, S.; Chang-Claude, J.; Webb, P.M.; Chen, X.; 
Beesley, J.; Chenevix-Trench, G.; Goode, E.L. Consortium analysis of 7 candidate SNPs for ovarian cancer. Int. J. Cancer 2008, 123, 380-388.

228. Camp, R.L.; Dolled-Filhart, M.; King, B.L.; Rimm, D.L. Quantitative analysis of breast cancer tissue microarrays shows that both high and normal levels of HER2 expression are associated with poor outcome. Cancer Res. 2003, 63, 1445-1448.

229. Camp, R.L.; Neumeister, V.; Rimm, D.L. A decade of tissue microarrays: progress in the discovery and validation of cancer biomarkers. J. Clin. Oncol. 2008, 26, 5630-5637.

230. de Jong, D.; Xie, W.; Rosenwald, A.; Chhanabhai, M.; Gaulard, P.; Klapper, W.; Lee, A.; Sander, B.; Thorns, C.; Campo, E.; Molina, T.; Hagenbeek, A.; Horning, S.; Lister, A.; Raemaekers, J.; Salles, G.; Gascoyne, R.D.; Weller, E. Immunohistochemical prognostic markers in diffuse large B-cell lymphoma: validation of tissue microarray as a prerequisite for broad clinical applications (a study from the Lunenburg Lymphoma Biomarker Consortium). J. Clin. Pathol. 2009, 62, 128-138.

231. McShane, L.M.; Altman, D.G.; Sauerbrei, W.; Taube, S.E.; Gion, M.; Clark, G.M. REporting recommendations for tumor MARKer prognostic studies (REMARK). Nat. Clin. Pract. Oncol. 2005, 2, 416-422.

232. Ransohoff, D.F. Bias as a threat to the validity of cancer molecular-marker research. Nat. Rev. Cancer 2005, 5, 142-149.

233. Ransohoff, D.F. How to improve reliability and efficiency of research about molecular markers: roles of phases, guidelines, and study design. J. Clin. Epidemiol. 2007, 60, 1205-1219.

234. Pepe, M.; Feng, Z.; Janes, H.; Bossuyt, P.M.; Potter, J.D. Pivotal evaluation of the accuracy of a biomarker used for classification or prediction: standards for study design. J. Natl. Cancer Inst. 2008, 100, 1432-1438.

235. Shah, S.P.; Kobel, M.; Senz, J.; Morin, R.D.; Clarke, B.A.; Wiegand, K.C.; Leung, G.; Zayed, A.; Mehl, E.; Kalloger, S.E.; Sun, M.; Giuliany, R.; Yorida, E.; Jones, S.; Varhol, R.; Swenerton, K.D.; Miller, D.; Clement, P.B.; Crane, C.; Madore, J.; Provencher, D.; Leung, P.; DeFazio, A.; Khattra, J.; Turashvili, G.; Zhao, Y.; Zeng, T.; Glover, J.N.; Vanderhyden, B.; Zhao, C.; Parkinson, C. A.; Jimenez-Linan, M.; Bowtell, D.D.; Mes-Masson, A.M.; Brenton, J.D.; Aparicio, S. A.; Boyd, N.; Hirst, M.; Gilks, C.B.; Marra, M.; Huntsman, D.G. Mutation of FOXL2 in granulosa-cell tumors of the ovary. N. Engl. J. Med. 2009, 360, 2719-2729.

236. Aparicio, S.A.; Huntsman, D.G. Does massively parallel DNA resequencing signify the end of histopathology as we know it? J. Pathol. 220, 307-315.

237. Tai, Y.T.; Lee, S.; Niloff, E.; Weisman, C.; Strobel, T.; Cannistra, S.A. BAX protein expression and clinical outcome in epithelial ovarian cancer. J. Clin. Oncol. 1998, 16, 2583-2590.

238. Yakirevich, E.; Sabo, E.; Naroditsky, I.; Sova, Y.; Lavie, O.; Resnick, M.B. Multidrug resistancerelated phenotype and apoptosis-related protein expression in ovarian serous carcinomas. Gynecol. Oncol. 2006, 100, 152-159.

239. Protopapas, A.; Diakomanolis, E.; Bamias, A.; Milingos, S.; Markaki, S.; Papadimitriou, C.; Dimopoulos, A.M.; Michalas, S. The prognostic significance of the immunohistochemical expression of p53, bcl-2, c-erb B-2 and cathepsin-D in ovarian cancer patients receiving platinum with cyclophosphamide or paclitaxel chemotherapy. Eur. J. Gynaecol. Oncol. 2004, 25, 225-229. 
240. Faleiro-Rodrigues, C.; Macedo-Pinto, I.; Pereira, D.; Lopes, C.S. Loss of beta-catenin is associated with poor survival in ovarian carcinomas. Int. J. Gynecol. Pathol. 2004, 23, 337-346.

241. Davidson, B.; Gotlieb, W.H.; Ben-Baruch, G.; Nesland, J.M.; Bryne, M.; Goldberg, I.; Kopolovic, J.; Berner, A. E-Cadherin complex protein expression and survival in ovarian carcinoma. Gynecol. Oncol. 2000, 79, 362-371.

242. Rubatt, J.M.; Darcy, K.M.; Hutson, A.; Bean, S.M.; Havrilesky, L.J.; Grace, L.A.; Berchuck, A.; Secord, A.A. Independent prognostic relevance of microvessel density in advanced epithelial ovarian cancer and associations between CD31, CD105, p53 status, and angiogenic marker expression: A Gynecologic Oncology Group study. Gynecol. Oncol. 2009, 112, 469-474.

243. Goodheart, M.J.; Vasef, M.A.; Sood, A.K.; Davis, C.S.; Buller, R.E. Ovarian cancer p53 mutation is associated with tumor microvessel density. Gynecol. Oncol. 2002, 86, 85-90.

244. Gadducci, A.; Ferrero, A.; Cosio, S.; Zola, P.; Viacava, P.; Dompe, D.; Fanelli, G.; Ravarino, N.; Motta, M.; Cristofani, R.; Genazzani, A. R. Intratumoral microvessel density in advanced epithelial ovarian cancer and its use as a prognostic variable. Anticancer Res. 2006, 26, 3925-3932.

245. Raspollini, M.R.; Amunni, G.; Villanucci, A.; Baroni, G.; Boddi, V.; Taddei, G.L. Prognostic significance of microvessel density and vascular endothelial growth factor expression in advanced ovarian serous carcinoma. Int. J. Gynecol. Cancer 2004, 14, 815-823.

246. Menczer, J.; Schreiber, L.; Kravtsov, V.; Berger, E.; Golan, A.; Levy, T. Cox-2 immunohistochemical expression in epithelial ovarian carcinoma and platin sensitivity. Eur. $J$. Gynaecol. Oncol. 2009, 30, 531-535.

247. Brustmann, H. Epidermal growth factor receptor expression in serous ovarian carcinoma: an immunohistochemical study with galectin-3 and cyclin D1 and outcome. Int. J. Gynecol. Pathol. 2008, 27, 380-389.

248. Ouellet, V.; Le Page, C.; Guyot, M.C.; Lussier, C.; Tonin, P.N.; Provencher, D.M.; Mes-Masson, A. M. SET complex in serous epithelial ovarian cancer. Int. J. Cancer 2006, 119, 2119-2126.

249. Darai, E.; Scoazec, J.Y.; Walker-Combrouze, F.; Mlika-Cabanne, N.; Feldmann, G.; Madelenat, P.; Potet, F. Expression of cadherins in benign, borderline, and malignant ovarian epithelial tumors: a clinicopathologic study of 60 cases. Hum. Pathol. 1997, 28, 922-928.

250. Schilder, R.J.; Sill, M. W.; Chen, X.; Darcy, K.M.; Decesare, S.L.; Lewandowski, G.; Lee, R.B.; Arciero, C.A.; Wu, H.; Godwin, A.K. Phase II study of gefitinib in patients with relapsed or persistent ovarian or primary peritoneal carcinoma and evaluation of epidermal growth factor receptor mutations and immunohistochemical expression: a Gynecologic Oncology Group Study. Clin. Cancer Res. 2005, 11, 5539-5548.

251. Kaufmann, M.; Von Minckwitz, G.; Kuhn, W.; Schmid, H.; Costa, S.; Goerttler, K.; Bastert, G. Combination of new biologic parameters as a prognostic index in epithelial ovarian carcinoma. Int. J. Gynecol. Cancer 1995, 5, 49-55.

252. Lassus, H.; Sihto, H.; Leminen, A.; Joensuu, H.; Isola, J.; Nupponen, N.N.; Butzow, R. Gene amplification, mutation, and protein expression of EGFR and mutations of ERBB2 in serous ovarian carcinoma. J. Mol. Med. 2006, 84, 671-681. 
253. Fischer-Colbrie, J.; Witt, A.; Heinzl, H.; Speiser, P.; Czerwenka, K.; Sevelda, P.; Zeillinger, R. EGFR and steroid receptors in ovarian carcinoma: comparison with prognostic parameters and outcome of patients. Anticancer Res. 1997, 17, 613-619.

254. Scambia, G.; Benedetti-Panici, P.; Ferrandina, G.; Distefano, M.; Salerno, G.; Romanini, M.E.; Fagotti, A.; Mancuso, S. Epidermal growth factor, oestrogen and progesterone receptor expression in primary ovarian cancer: correlation with clinical outcome and response to chemotherapy. Br. J. Cancer 1995, 72, 361-366.

255. Lin, C.K.; Chao, T.K.; Yu, C.P.; Yu, M.H.; Jin, J.S. The expression of six biomarkers in the four most common ovarian cancers: correlation with clinicopathological parameters. APMIS 2009, $117,162-175$.

256. Nielsen, J.S.; Jakobsen, E.; Holund, B.; Bertelsen, K.; Jakobsen, A. Prognostic significance of p53, Her-2, and EGFR overexpression in borderline and epithelial ovarian cancer. Int. J. Gynecol. Cancer 2004, 14, 1086-1096.

257. Xia, W.; Wei, Y.; Du, Y.; Liu, J.; Chang, B.; Yu, Y.L.; Huo, L.F.; Miller, S.; Hung, M.C. Nuclear expression of epidermal growth factor receptor is a novel prognostic value in patients with ovarian cancer. Mol. Carcinog. 2009, 48, 610-617.

258. Lin, H.; Changchien, C.C. Management of relapsed/refractory epithelial ovarian cancer: current standards and novel approaches. Taiwan J. Obstet. Gynecol. 2007, 46, 379-388.

259. Stadlmann, S.; Dirnhofer, S.; Guth, U.; Thies, S.; Singer, G. ERCC1-immunoexpression does not predict platinum-resistance in ovarian cancer. Gynecol. Oncol. 2008, 108, 252-253.

260. Obermair, A.; Speiser, P.; Reisenberger, K.; Ullrich, R.; Czerwenka, K.; Kaider, A.; Zeillinger, R.; Miksche, M. Influence of intratumoral basic fibroblast growth factor concentration on survival in ovarian cancer patients. Cancer Lett. 1998, 130, 69-76.

261. Hoopmann, M.; Sachse, K.; Valter, M.M.; Becker, M.; Neumann, R.; Ortmann, M.; Gohring, U.J.; Thomas, A.; Mallmann, P.; Schondorf, T. Serological and immunohistochemical HER2/neu statuses do not correlate and lack prognostic value for ovarian cancer patients. Eur. J. Cancer Care (Engl.) 2010, doi: 10.1111/j.1365-2354.2009.01112.x

262. Castellvi, J.; Garcia, A.; de la Torre, J.; Hernandez, J.; Gil, A.; Xercavins, J.; Ramon y Cajal, S. Ephrin B expression in epithelial ovarian neoplasms correlates with tumor differentiation and angiogenesis. Hum. Pathol. 2006, 37, 883-889.

263. Rubin, S.C.; Finstad, C.L.; Wong, G.Y.; Almadrones, L.; Plante, M.; Lloyd, K.O. Prognostic significance of HER-2/neu expression in advanced epithelial ovarian cancer: a multivariate analysis. Am. J. Obstet. Gynecol. 1993, 168, 162-169.

264. Pils, D.; Pinter, A.; Reibenwein, J.; Alfanz, A.; Horak, P.; Schmid, B. C.; Hefler, L.; Horvat, R.; Reinthaller, A.; Zeillinger, R.; Krainer, M. In ovarian cancer the prognostic influence of HER2/neu is not dependent on the CXCR4/SDF-1 signalling pathway. Br. J. Cancer 2007, 96, 485-491.

265. Hogdall, E.V.; Christensen, L.; Kjaer, S.K.; Blaakaer, J.; Bock, J.E.; Glud, E.; NorgaardPedersen, B.; Hogdall, C.K. Distribution of HER-2 overexpression in ovarian carcinoma tissue and its prognostic value in patients with ovarian carcinoma: from the Danish MALOVA Ovarian Cancer Study. Cancer 2003, 98, 66-73. 
266. Sasaki, N.; Kudoh, K.; Kita, T.; Tsuda, H.; Furuya, K.; Kikuchi, Y. Effect of HER-2/neu overexpression on chemoresistance and prognosis in ovarian carcinoma. J. Obstet. Gynaecol. Res. 2007, 33, 17-23.

267. Verri, E.; Guglielmini, P.; Puntoni, M.; Perdelli, L.; Papadia, A.; Lorenzi, P.; Rubagotti, A.; Ragni, N.; Boccardo, F. HER2/neu oncoprotein overexpression in epithelial ovarian cancer: evaluation of its prevalence and prognostic significance. Clinical study. Oncology 2005, 68, 154-161.

268. Tuefferd, M.; Couturier, J.; Penault-Llorca, F.; Vincent-Salomon, A.; Broet, P.; Guastalla, J.P.; Allouache, D.; Combe, M.; Weber, B.; Pujade-Lauraine, E.; Camilleri-Broet, S. HER2 status in ovarian carcinomas: a multicenter GINECO study of 320 patients. PLoS One 2007, 2, e1138.

269. Pfisterer, J.; Du Bois, A.; Bentz, E.K.; Kommoss, F.; Harter, P.; Huober, J.; Schmalfeldt, B.; Burchardi, N.; Arnold, N.; Hilpert, F. Prognostic value of human epidermal growth factor receptor 2 (Her-2)/neu in patients with advanced ovarian cancer treated with platinum/paclitaxel as first-line chemotherapy: a retrospective evaluation of the AGO-OVAR 3 Trial by the AGO OVAR Germany. Int. J. Gynecol. Cancer 2009, 19, 109-115.

270. Berchuck, A.; Kamel, A.; Whitaker, R.; Kerns, B.; Olt, G.; Kinney, R.; Soper, J.T.; Dodge, R.; Clarke-Pearson, D.L.; Marks, P.; et al. Overexpression of HER-2/neu is associated with poor survival in advanced epithelial ovarian cancer. Cancer Res. 1990, 50, 4087-4091.

271. Elpek, G.O.; Karaveli, S.; Simsek, T.; Keles, N.; Aksoy, N.H. Expression of heat-shock proteins hsp27, hsp70 and hsp90 in malignant epithelial tumour of the ovaries. APMIS 2003, 111, 523-530.

272. Surowiak, P.; Materna, V.; Klak, K.; Spaczynski, M.; Dietel, M.; Kristiansen, G.; Lage, H.; Zabel, M. Prognostic value of immunohistochemical estimation of CD24 and Ki67 expression in cisplatin and paclitaxel treated ovarian carcinoma patients. Pol. J. Pathol. 2005, 56, 69-74.

273. Kaern, J.; Aghmesheh, M.; Nesland, J.M.; Danielsen, H.E.; Sandstad, B.; Friedlander, M.; Trope, C. Prognostic factors in ovarian carcinoma stage III patients. Can biomarkers improve the prediction of short- and long-term survivors? Int. J. Gynecol. Cancer 2005, 15, 1014-1022.

274. Rose, S.L.; Robertson, A.D.; Goodheart, M.J.; Smith, B.J.; DeYoung, B.R.; Buller, R.E. The impact of 553 protein core domain structural alteration on ovarian cancer survival. Clin. Cancer Res. 2003, 9, 4139-4144.

275. Duncan, T.J.; Al-Attar, A.; Rolland, P.; Harper, S.; Spendlove, I.; Durrant, L.G. Cytoplasmic p27 expression is an independent prognostic factor in ovarian cancer. Int. J. Gynecol Pathol. 2010, 29, 8-18.

276. Laframboise, S.; Chapman, W.; McLaughlin, J.; Andrulis, I.L. p53 mutations in epithelial ovarian cancers: possible role in predicting chemoresistance. Cancer J. 2000, 6, 302-308.

277. Henriksen, R.; Strang, P.; Wilander, E.; Backstrom, T.; Tribukait, B.; Oberg, K. p53 expression in epithelial ovarian neoplasms: relationship to clinical and pathological parameters, Ki-67 expression and flow cytometry. Gynecol. Oncol. 1994, 53, 301-306.

278. Levesque, M.A.; Katsaros, D.; Yu, H.; Zola, P.; Sismondi, P.; Giardina, G.; Diamandis, E.P. Mutant p53 protein overexpression is associated with poor outcome in patients with well or moderately differentiated ovarian carcinoma. Cancer 1995, 75, 1327-1338. 
279. Eltabbakh, G.H.; Belinson, J.L.; Kennedy, A.W.; Biscotti, C.V.; Casey, G.; Tubbs, R.R.; Blumenson, L.E. p53 overexpression is not an independent prognostic factor for patients with primary ovarian epithelial cancer. Cancer 1997, 80, 892-898.

280. Yamamoto, S.; Tsuda, H.; Honda, K.; Kita, T.; Takano, M.; Tamai, S.; Inazawa, J.; Yamada, T.; Matsubara, O. Actinin-4 expression in ovarian cancer: a novel prognostic indicator independent of clinical stage and histological type. Mod. Pathol. 2007, 20, 1278-1285.

281. Klemi, P.J.; Pylkkanen, L.; Kiilholma, P.; Kurvinen, K.; Joensuu, H. p53 protein detected by immunohistochemistry as a prognostic factor in patients with epithelial ovarian carcinoma. Cancer 1995, 76, 1201-1208.

282. Shahin, M.S.; Hughes, J.H.; Sood, A. K.; Buller, R.E. The prognostic significance of p53 tumor suppressor gene alterations in ovarian carcinoma. Cancer 2000, 89, 2006-2017.

283. Reles, A.; Wen, W.H.; Schmider, A.; Gee, C.; Runnebaum, I.B.; Kilian, U.; Jones, L.A.; El-Naggar, A.; Minguillon, C.; Schonborn, I.; Reich, O.; Kreienberg, R.; Lichtenegger, W.; Press, M.F. Correlation of p53 mutations with resistance to platinum-based chemotherapy and shortened survival in ovarian cancer. Clin. Cancer Res. 2001, 7, 2984-2997.

284. Hartmann, L.C.; Podratz, K.C.; Keeney, G.L.; Kamel, N.A.; Edmonson, J.H.; Grill, J.P.; Su, J.Q.; Katzmann, J. A.; Roche, P.C. Prognostic significance of p53 immunostaining in epithelial ovarian cancer. J. Clin. Oncol. 1994, 12, 64-69.

285. Gadducci, A.; Ciancia, E.M.; Campani, D.; Malagnino, G.; De Luca, F.; Facchini, V.; Pingitore, R.; Fioretti, P. Immunohistochemical detection of p185 product, p21 product, and proliferating cell nuclear antigen (PCNA) in formalin-fixed, paraffin-embedded tissues from ovarian carcinomas. Preliminary data. Eur. J. Gynaecol. Oncol. 1994, 15, 359-368.

286. Ferrandina, G.; Legge, F.; Martinelli, E.; Ranelletti, F.O.; Zannoni, G.F.; Lauriola, L.; Gessi, M.; Gallotta, V.; Scambia, G. Survivin expression in ovarian cancer and its correlation with clinicopathological, surgical and apoptosis-related parameters. Br. J. Cancer 2005, 92, 271-277.

287. Cornarotti, M.; Capranico, G.; Bohm, S.; Oriana, S.; Spatti, G.B.; Mariani, L.; Ballabio, G.; Zunino, F. Gene expression of DNA topoisomerases I, II alpha and II beta and response to cisplatin-based chemotherapy in advanced ovarian carcinoma. Int. J. Cancer 1996, 67, 479-484.

288. Costa, M.J.; Hansen, C.L.; Holden, J.A.; Guinee, D., Jr. Topoisomerase II alpha: prognostic predictor and cell cycle marker in surface epithelial neoplasms of the ovary and peritoneum. Int. J. Gynecol. Pathol. 2000, 19, 248-257.

(C) 2010 by the authors; licensee MDPI, Basel, Switzerland. This article is an Open Access article distributed under the terms and conditions of the Creative Commons Attribution license (http://creativecommons.org/licenses/by/3.0/). 